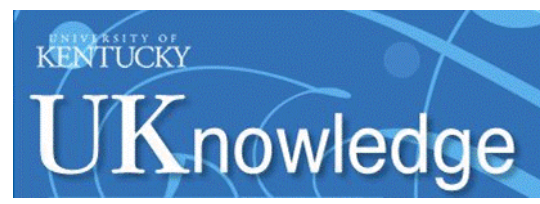

University of Kentucky

UKnowledge

2015

\title{
Animal and Pasture Responses to Grazing Management of Chemically Suppressed Tall Fescue in Mixed Pastures
}

Jessica A. Williamson

University of Kentucky, jessica.williamson@uky.edu

Right click to open a feedback form in a new tab to let us know how this document benefits you.

\section{Recommended Citation}

Williamson, Jessica A., "Animal and Pasture Responses to Grazing Management of Chemically Suppressed Tall Fescue in Mixed Pastures" (2015). Theses and Dissertations--Plant and Soil Sciences. 57. https://uknowledge.uky.edu/pss_etds/57

This Doctoral Dissertation is brought to you for free and open access by the Plant and Soil Sciences at UKnowledge. It has been accepted for inclusion in Theses and Dissertations--Plant and Soil Sciences by an authorized administrator of UKnowledge. For more information, please contact UKnowledge@lsv.uky.edu. 


\section{STUDENT AGREEMENT:}

I represent that my thesis or dissertation and abstract are my original work. Proper attribution has been given to all outside sources. I understand that I am solely responsible for obtaining any needed copyright permissions. I have obtained needed written permission statement(s) from the owner(s) of each third-party copyrighted matter to be included in my work, allowing electronic distribution (if such use is not permitted by the fair use doctrine) which will be submitted to UKnowledge as Additional File.

I hereby grant to The University of Kentucky and its agents the irrevocable, non-exclusive, and royalty-free license to archive and make accessible my work in whole or in part in all forms of media, now or hereafter known. I agree that the document mentioned above may be made available immediately for worldwide access unless an embargo applies.

I retain all other ownership rights to the copyright of my work. I also retain the right to use in future works (such as articles or books) all or part of my work. I understand that I am free to register the copyright to my work.

\section{REVIEW, APPROVAL AND ACCEPTANCE}

The document mentioned above has been reviewed and accepted by the student's advisor, on behalf of the advisory committee, and by the Director of Graduate Studies (DGS), on behalf of the program; we verify that this is the final, approved version of the student's thesis including all changes required by the advisory committee. The undersigned agree to abide by the statements above.

Jessica A. Williamson, Student

Dr. Glen E. Aiken, Major Professor

Dr. Mark S. Coyne, Director of Graduate Studies 


\title{
ANIMAL AND PASTURE RESPONSES TO GRAZING MANAGEMENT OF CHEMICALLY SUPPRESSED \\ TALL FESCUE IN MIXED PASTURES
}

\section{DISSERTATION}

A dissertation submitted in partial fulfillment of the requirements for the degree of Doctor of Philosophy in the College of Agriculture, Food, and Environment at the University of Kentucky

\author{
By \\ Jessica A. Williamson \\ Lexington, Kentucky
}

Co-Directors: Dr. Glen E. Aiken, Adjunct Professor of Plant and Soil Science and Dr. Michael Barrett, Professor of Plant and Soil Science

Lexington, Kentucky

Copyright $@$ Jessica A. Williamson 2015 


\section{ABSTRACT OF DISSERTATION}

\section{ANIMAL AND PASTURE RESPONSES TO GRAZING MANAGEMENT OF CHEMICALLY SUPPRESSED TALL FESCUE IN MIXED PASTURES}

Treatment of endophyte-infected tall fescue [Lolium arundinaceum (Schreb.) Darbysh] with the broad leaf herbicide Chaparral ${ }^{\circledR}$ can mitigate fescue toxicosis and enhance forage quality by suppressing seedhead emergence. Applying the herbicide to fescue pastures also reduces forage mass and promotes severe spot grazing when pastures are continuously grazed. A grazing experiment was conducted with steers (2013) and heifers (2014) to evaluate animal and plant responses in fescue-bluegrass (Poa pratensis L.) mixtures treated with Chaparral to determine the effects of grazing management on pasture carrying capacity, nutritive values, botanical composition, and animal performance. Continuous and rotational (i.e., four subdivisions to provide a 7-d grazing period and a 21-d rest period) grazing treatments were assigned to six, 3.0-ha fescue- bluegrass pastures in a randomized complete block design with three replications. Each pasture had six tester animals, and stocking rates were varied using put-and-take animals. Pastures were grazed from 16 April to 8 July 2013 (Year 1) and 20 May to 12 Aug (Year 2) and cattle were blocked by body weight for allotment to pasture. Pasture carrying capacities were greater $(P=0.07)$ for rotational compared to continuous pastures across both years. Calves on rotationally grazed pastures had greater average daily gain $(P=0.03)$ and gain per acre $(P=0.05)$ than those on the continuous treatment across both years. Canopies of continuously grazed pastures contained less $(P$ $=0.01)$ tall fescue than those in rotationally grazed pastures. Herbage in pre-grazed paddocks had less NDF and ADF than post-grazed paddocks and continuously grazed pastures in $2013(P<0.10)$, but did not differ in $2014(P>0.10)$. In vitro digestible dry matter was greater $(P=0.07)$ in pre-graze rotational pastures in 2013 compared with continuous and post-graze rotational, and IVDDM did not differ $(P<0.01)$ between pregraze rotational and continuous in 2014 , but was greater than post-graze rotational. Crude protein was lower $(P=0.06)$ in both years in post-graze rotational pasture than in continuous or pre-graze rotational pasture, which did not differ. In 2013, there was no difference $(P=0.60)$ in root WSC among treatments; however, in 2014, WSC levels were greater $(P=0.01)$ in rotationally grazed pastures compared with continuously grazed pastures. This grazing experiment indicated that rotational grazing of Chaparral treated fescue-bluegrass mixtures can improve both animal performance and the sustainability of pasture productivity. 
KEYWORDS: Tall Fescue Toxicosis, Grazing Management, Chemical Seedhead Suppression, Tall Fescue, Pasture Productivity

Jessica A. Williamson 


\section{ANIMAL AND PASTURE RESPONSES TO GRAZING MANAGEMENT OF CHEMICALLY SUPPRESSED TALL FESCUE IN MIXED PASTURES}

\section{By}

Jessica A. Williamson

Dr. Glen E. Aiken, Co-Director of Dissertation

Dr. Michael Barrett, Co-Director of Dissertation

Dr. Mark S. Coyne, Director of Graduate Studies

3 February 2015 


\section{DEDICATION}

This dissertation and all that it represents is dedicated to my father, T.R. Robinette, who instilled in me a love and passion for agriculture that traces back to my earliest memories of life, and who helped me understand the importance of stewardship of the land and livestock which we were blessed with by our Creator; to my mother, Cindy Robinette, who has forever believed in me, encouraged me to reach for the stars, and taught me that no dream is too big to achieve; and to my husband, Ben Williamson, whose loving devotion and unfaltering faith has given me the courage to fly. 


\section{ACKNOWLEDGEMENTS}

Thank you to my advisor, Dr. Glen Aiken, for your guidance, dedication, and continued support throughout the entirety of my doctoral program, as well as affording me the opportunity to continue my education by pursuing a doctoral degree. I would also like to thank my co-advisor, Dr. Michael Barrett for his direction and support throughout my time spent at the University of Kentucky. Thank you to my committee members Dr. Ben Goff, Dr. Jeff Lehmkuhler, and Dr. Mark Coyne for their time and assistance in my dissertation preparation and guidance during my program.

Thank you to Tracy Hamilton for technical assistance and encouragement throughout my time at the University of Kentucky, and to the USDA-ARS Forage Animal Research Production Unit and the Department of Plant and Soil Sciences for their support, encouragement, and assistance during my $\mathrm{PhD}$ program. I would like to thank Dow AgroSciences Pasture and Range for funding my research and would like extend a note of appreciation to Dr. Scott Flynn, Dave Owens, Jeff Clark, and Whitney Murphy for all of their assistance.

Finally, I would like to give a special thank you to my family who have continuously supported and believed in me through all of my endeavors in life and for instilling in me faith in a Greater Power; God will direct our paths, and we must have the courage to follow it. 


\section{TABLE OF CONTENTS}

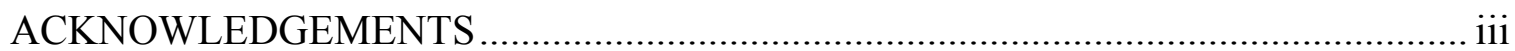

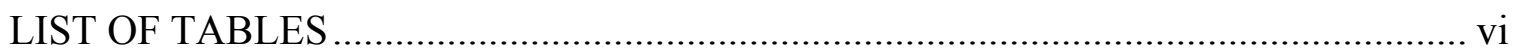

LIST OF FIGURES ..................................................................................... vii

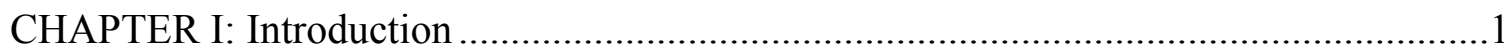

CHAPTER II: Literature Review...........................................................................

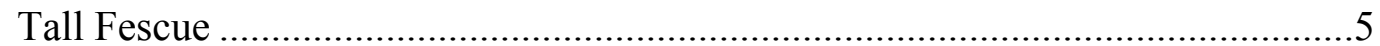

Epichloë Coenophialia ...................................................................... 7

Ergot Alkaloids .................................................................................

Negative Effects of Endophyte-Infected Tall Fescue in Grazing Animal

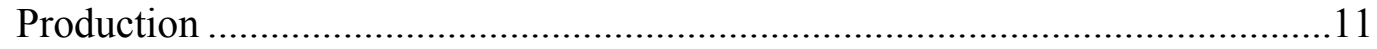

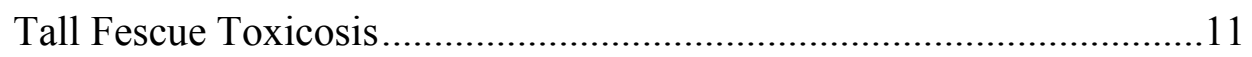

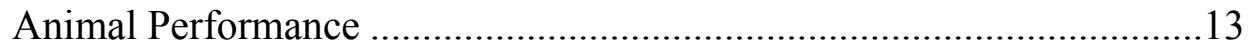

Reproductive Performance ............................................................. 16

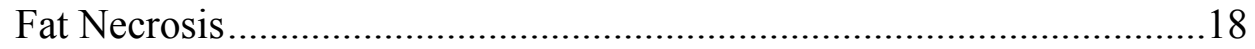

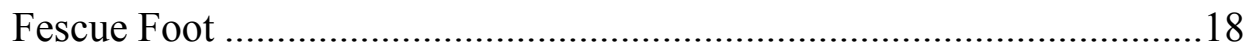

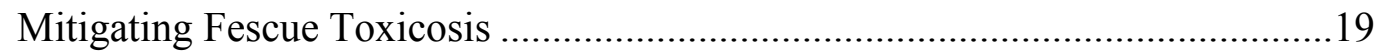

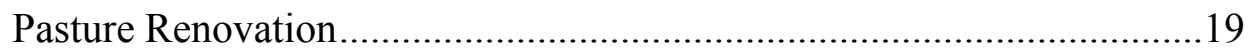

Mechanical Removal of Seedheads.....................................................20

Grazing Management ....................................................................20

Dilution with Legumes.................................................................23

Feeding Concentrates or Co-Product Feeds .......................................23

Genetic Improvement in Grazing Animals .........................................24

Chemical Suppression of Tall Fescue Seedhead Emergence..................25

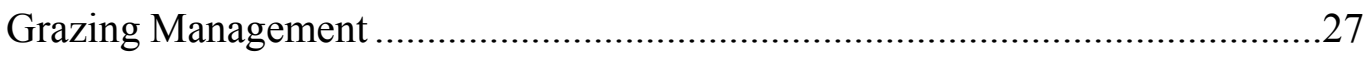

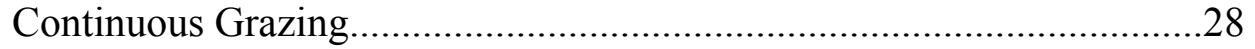

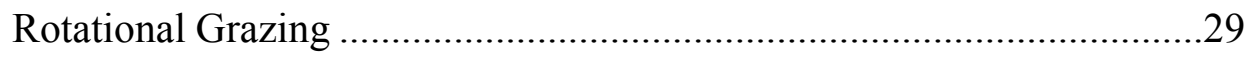

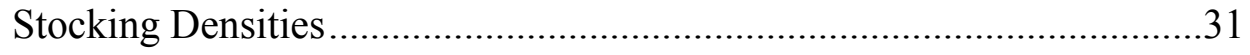


Carry-Over of Alkaloids in the Animal

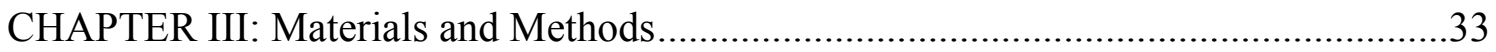

Experimental Design, Grazing, and Pasture Management.................................33

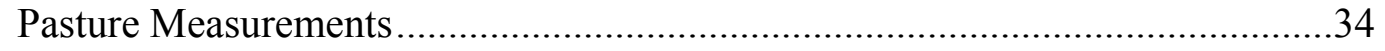

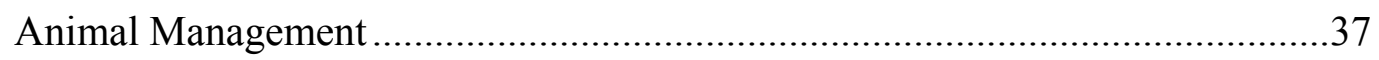

Calculations and Statistical Analyses........................................................... 37

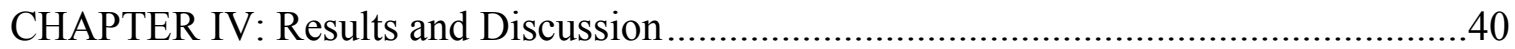

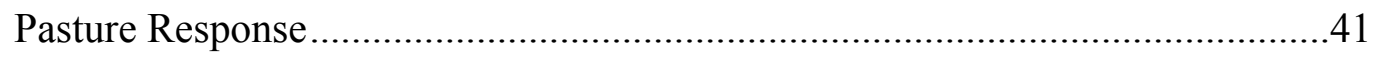

Ergovaline and Ergovalinine Concentrations in Whole Tillers .........................45

Nutritive Values of Quadrat Samples..............................................................47

Pasture Carrying Capacity ........................................................................51

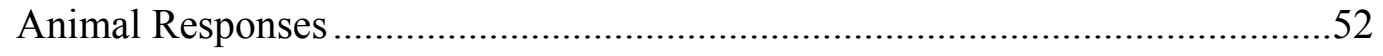

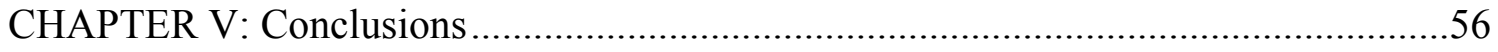

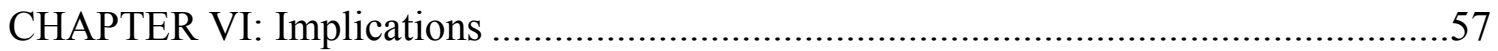

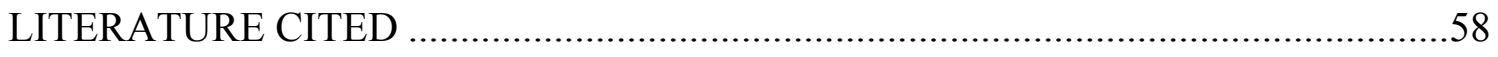

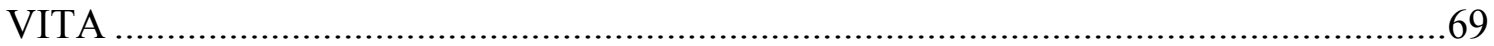




\section{LIST OF TABLES}

Table 1. Average disk meter height (DMH) and forage mass (FM) for continuously and rotationally grazed pastures of a mixture of toxic tall fescue, bluegrass, orchardgrass, and other species

Table 2. Botanical compositions in the canopies of pastures for continuously and rotationally grazed treatments

Table 3. Mean neutral detergent fiber (NDF), acid detergent fiber (ADF), and in vitro digestible dry matter (IVDDM) in quadrats $\left(0.25 \mathrm{~m}^{2}\right)$ clipped in continuously and rotationally grazed pastures

Table 4. Crude protein (CP) and water-soluble carbohydrates (WSC) for quadrat samples $(0.25 \mathrm{~m} 2)$ from continuously and rotationally grazed pastures across years

Table 5. Carrying capacity (CC), stocking rate (SR), and forage availability (FA) of treatments across both years 


\section{LIST OF FIGURES}

Figure 1. Total precipitation for April to August during the grazing seasons in 2013,2014 , and the 30 -yr average

Figure 2. Ergovaline concentrations of tall fescue tiller samples across sampling dates 46

Figure 3. Water soluble carbohydrates (WSC) for tall fescue root samples from continuously and rotationally grazed pastures across years .50

Figure 4. Average Daily Gain (kg) of continuously and rotationally grazed pastures across bothyears

Figure 5. Gain per hectare $\left(\mathrm{kg} \mathrm{BW} \mathrm{ha}^{-1}\right)$ of continuously and rotationally grazed pastures across bothyears 


\section{CHAPTER I: Introduction}

Tall fescue [Lolium arundinaceum (Schreb.) Darbysh] possesses a symbiotic relationship with a fungal endophyte, Epicloë coenophialia (Leuchtmann et al., 2014), which provides the plant desirable hardiness and persistence in adverse environmental conditions. Wild-type endophyte-infected tall fescue is known for its ability to thrive and conserve soil on thin-soiled, droughty slopes while still forming a deep-rooted, dense sod, and performing well on poorly- drained soils (Buckner et al., 1979). Its desirable hardiness coupled with its moderate nutritive value caused the forage's popularity to grow rapidly across the U.S. transition zone after its discovery in 1931 (Buckner et al., 1979).

Ergot alkaloids are mycotoxins produced by endophytic fungi that are naturally occurring within a plant and are the primary causative agent for the development of fescue toxicosis (Roberts et al., 2004; Bush and Fannin, 2009). The fescue endophyte produces ergot alkaloids that negatively affect the performance and physiology of grazing animals (Bacon et al., 1986). Of the various ergopeptine alkaloids produced, ergovaline is the most toxic in altering the physiology of the animal (Klotz et al., 2007) and is in the highest concentration in the plant (Lyons et al., 1986), particularly in the seedhead of the plant (Rottinghaus et al., 1991).

Signs of fescue toxicosis in cattle are the retention of rough hair coats, elevated core body temperatures, labored breathing, general unthrifty appearance, and poor performance (Hoveland et al., 1983; Hemken et al., 1984). Toxicosis symptoms that are not visible can be more harmful to the animal. These symptoms include 
vasoconstriction, which restricts blood flow to the extremities and ultimately elevates core body temperatures; increased respiration; decreased serum and plasma prolactin concentrations (Roberts et al., 2004). An estimated combined loss of all grazing animal industries that could be affected by endophyte-infected tall fescue exceeds $\$ 1$ billion USD annually, making tall fescue toxicosis the largest animal health-related production cost for the livestock industry in the United States (Strickland et al., 2011).

Mitigation strategies to alleviate fescue toxicosis include two main strategies: 1) renovating pastures containing toxic endophyte-infected tall fescue with other tall fescue varieties that either do not contain an endophyte or contain a novel endophyte that does not produce the toxic ergot alkaloids; 2) mechanically removing seedheads by mowing and employing a high stocking rate (Bransby et al., 1988). Other strategies include rotationally grazing fescue pastures (Ball et al., 2007), diluting the pasture with other forages (McMurphy et al., 1990), and supplementing the grazing animal's diet with co-products to increase the animal's plane of nutrition (Carter et al., 2010). The seedheads of endophyte-infected tall fescue can contain up to three times greater concentration of ergovaline than the rest of the plant (Rottinghaus et al., 1991). The incidence of toxicosis symptoms could be greatly reduced by eliminating a major source for most of the ergovaline consumption, the seedhead, which have shown to have a six- to ten-fold greater concentration of ergovaline compared to other parts of the plant (Aiken et al., 2012).

Chemical seedhead suppression in toxic endophyte-infected tall fescue was first studied using the herbicide mefluidide (a plant growth regulator) to delay maturity by treating fescue in early spring and suppress seedhead emergence (Sheaffer and 
Marten, 1986; Turner et al., 1990). Treating cool-season perennial grasses with mefluidide has enhanced forage quality into the late spring and summer (Sheaffer and Marten, 1986) and provided increased animal gains on toxic tall fescue pastures compared to untreated pastures (Turner et al., 1990). However, mefluidide was never licensed for use on grazed pastures, restricting its use to suppress seedhead emergence in tall fescue (Aiken and Strickland, 2013).

Recent studies have evaluated specialty herbicides that reduce seedhead emergence in tall fescue (Aiken et al., 2012). Metsulfuron-methyl inhibits reproductive growth stages by suppressing seedhead emergence in tall fescue and allows the grass to remain in vegetative growth for the duration of the growing season. The active ingredient, Metsulfuron-methyl, does not suppress seed head emergence of Kentucky bluegrass (Poa Pratensis L.) or orchardgrass (Dactylis glomerata L.) (Aiken et al., 2012; Goff, 2012).

Aiken et al. (2012) reported that in lightly-grazed mixed cool-season grass pastures that were treated or not treated with metsulfuron for seedhead suppression, the incidence of seedheads were nearly 10 -fold greater in untreated than treated pastures. Although seedhead emergence declined, forage mass also declined. There was no difference in the ergovaline concentrations in vegetative tissues between treatments; however, forage from the treated pastures had greater crude protein, in vitro dry matter digestibility (IVDMD), and water-soluble carbohydrates (WSC) compared to untreated pastures (Aiken et al., 2012). Animals grazing chemicallytreated pastures exhibited greater average daily gains (ADG) and had greater serum prolactin concentrations, which indicated there was mitigation of toxicosis. 
Goff et al. (2012) evaluated plant and steer performance in continuously grazed endophyte-free tall fescue pastures with combinations of with or without Chaparral application and low and moderate grazing intensities. Chemically-treated pastures had reduced seedhead emergence and greater forage nutritive values. Across the two grazing intensities, steers grazing seedhead suppressed pastures gained $0.95 \mathrm{~kg} \mathrm{~d}^{-1}$, compared to $0.79 \mathrm{~kg} \mathrm{~d}^{-1}$ for steers on unsuppressed pastures (Goff et al., 2012).

Both Aiken et al. (2012) and Goff (2012) reported seedhead suppressed pastures to have reduced forage mass that could limit pasture carrying capacities. Although Goff (2012) observed greater average daily gain ADG by steers grazing seed head suppressed pastures, the lower carrying capacities of these pastures resulted in body weight $(\mathrm{BW})$ gain per ha being greater in unsuppressed pastures. Further, both Aiken et al. (2012) and Goff (2012) noted that, under the continuous grazing method used in these experiments, selective grazing of seed heads suppressed tall fescue caused excessive spot grazing that could reduce persistence. Rotational grazing systems could be useful in enhancing carrying capacities and sustainability of chemically seed head suppressed tall fescue pastures. Therefore, the objectives of this study were to determine the effects of rotational grazing of endophyte-infected tall fescue treated with metsulfuron in mixture with Kentucky bluegrass and orchardgrass (Dactylis glomerata L.) on: (1) forage stand persistence and production; (2) pasture nutritive values and tiller ergovaline concentrations; (3) animal performance. 


\section{CHAPTER II: Literature Review}

\section{TALL FESCUE}

Tall fescue [Lolium arundinaceum (Schreb.) Darbysh] is a cool-season perennial grass that is native to Europe and North Africa and was introduced into North and South America from Europe (Borrill, 1976). It is believed that tall fescue originally entered the United States as a contaminant in other forage grass seeds (Studemann et al., 1988). Lamson-Scribner (1896) in the late-nineteenth century concluded that tall fescue was an exceedingly valuable forage as both hay or pasture and could be productive on soils that were not too dry, which made it especially valuable for permanent pastures.

An ecotype of tall fescue was originally found growing prior to 1890 on the Suiter farm in Menifee County, Kentucky (Buckner et al., 1979). Seed was obtained from the site by E.N. Fergus at the University of Kentucky and small-plot trials were conducted from 1931 to 1943 at the Kentucky Agricultural Experiment Station and several locations across the state of Kentucky (Buckner et al., 1979). The 'Kentucky 31' cultivar was eventually released by the University of Kentucky in 1943.Its prominent features included dependability, adaptability to a wide range of soils, the ability to afford grazing during most of the year, and palatability to livestock (Fergus, 1952; Fergus and Buckner, 1972). Tall fescue was quickly recognized to have soilconserving qualities and nearly year-round grazing value, and plantings on erodible, rolling hills were rapidly adopted by Kentucky farmers (Buckner et al., 1979). By 1973, tall fescue inhabited approximately 12 to 14 million hectares across the eastern 
United States. Its ability to thrive and conserve soil on thin-soiled, droughty slopes while still forming a deep-rooted, dense sod, or performing well on poorly-drained soils resulted in tall fescue's popularity growing rapidly across the nation (Buckner et al., 1979). Hay yields of tall fescue average 2 to 5 tons $\mathrm{ac}^{-1}$ and have moderate nutritive value $(10-15 \% \mathrm{CP}$ and $55-60 \% \mathrm{TDN}$; Ball et al., 2007). Tall fescue thrives primarily in the transition zone of the United States between the temperate northeast and subtropical southeast, but is adapted in areas ranging from northern Florida to southern Canada (Buckner et al., 1979). An estimated fifteen million hectares in the United States are covered with tall fescue (Bacon et al., 1986) and over 8.5 million beef cows are grazed on tall fescue pastures (Ball et al., 2007).

As tall fescue gained popularity and became more prevalent in pastures and hay fields across the United States, producers quickly noticed reduced animal performance in grazed tall fescue pastures (Pratt and Haynes, 1950). Fescue appeared to have high forage quality with digestible dry matter (DM), crude protein (CP), amino acid, and mineral content that could rival other cool-season forages in producing good animal performance if managed well (Bush and Buckner, 1973). However, cattle gains on tall fescue were disturbingly low and typically below $0.5 \mathrm{~kg} \mathrm{~d}^{-1}$ for the grazing season (Blaser et al., 1956; Mott et al., 1971).

Neill (1941) in New Zealand showed that tall fescue was susceptible to infection by an endophyte and in 1973 A.E. Hays observed on his farm near Mansfield, Georgia that cattle in one 32-ha tall fescue pasture exhibited negative production signs while cattle in another 32-ha tall fescue pasture did not show any adverse symptoms (Robbins, 1983). A hypothesis was made that an endophytic fungus 
might be the cause of the adverse effects on animals grazing tall fescue. A sample of fescue from each pasture, and additional samples from across Georgia and four other states were collected and analyzed and a fungus, classified as Epichloe typhina, was found to be associated with the adverse effects on grazing livestock (Bacon et al., 1977). This endophyte was reclassified as Acremonium coenophialum (Morgan-Jones and Gams, 1982) then as Neotyphodium coenophialum (Glenn et al., 1996).

Neotyphodium coenophialum was reclassified in 2014 as Epicloë coenophialia (Leuchtmann et al., 2014).

\section{Epicloë coenophiala}

Tall fescue possesses a symbiotic relationship with a fungal endophyte, Epicloë coenophiala, which produces ergot alkaloids that can negatively affect the performance and physiology of grazing animals (Bacon et al., 1986). The hyphae (the thread-like microfilaments forming the mycelium) of the endophyte ("endo" = within, "phyte" = plant) live within extracellular spaces in plant tissues (Christensen and Voisey, 2007). They have primarily a parallel orientation to the longitudinal leaf axis and are attached to the plant cells. The plant cells seem to be unaffected by the attachment of the fungal hyphae and the hyphae's growth is regulated by the plant growth rate.

Within the leaf blade, endophyte hyphae are located in clusters and as the plant ages the diameter but not the number of hyphae increases (Christensen and Voisey, 2007). Christensen et al. (2002) determined that the growth of the endophyte keeps pace with the growth of the host and once the hyphae become mature they do not continue to extend in growth or form any more branches but remain metabolically 
active within the plant and grow wider with age. The endophyte becomes active in the plant when the seed germinates and continues to be metabolically active during the entire lifetime of the plant, growing at the pace of the seedling. After extension of the hyphae ceases and the endophyte remains metabolically active, it retains cytoplasm and accumulates protein crystals and tubal bodies (Christensen et al., 2002). The formation and accumulation of lipid droplets in metabolically active endophytes indicates that they could be utilizing nutrients produced by the plant; however, it appears that the infected host plant is not negatively affected by the utilization of these nutrients by the fungus (Latch et al., 1985).

The host genotype strongly influences the biomass of the hyphae, the frequency of presence of hyphae among the vascular bundles, and the concentration and ratio of alkaloids produced by the endophyte (Christensen et al., 1997, Christensen et al., 2007). It is hypothesized that the host plant sends a signal to the endophyte that regulates the synchronization of hyphal growth (Christensen et al., 2007).

\section{ERGOT ALKALOIDS}

Ergot alkaloids are mycotoxins produced by naturally occurring endophytic fungi within a plant and are the primary causative agent for the development of fescue toxicosis (Roberts et al., 2004; Bush and Fannin, 2009). These alkaloids contain a tetracyclic ergoline ring structure (Berde, 1980) and include: clavine alkaloids, lysergic acid amides, and ergopeptines (Bacon et al., 1977; Porter, 1995; Bush and Fannin, 2009). Of the major classes of ergot alkaloids, the D- lysergic acid derivatives (ergopeptines) are the major causative agent of fescue toxicosis while its epimer, D- 
isolysergic acid, does not have any biological effect reported within animals (Berde, 1980).

Of the various types of alkaloids produced, ergovaline has the most significant impact on negatively affecting the physiology of the animal (Klotz et al., 2007).

Although it is present throughout the entire plant, it is at its greatest concentrations in the seedhead (Rottinghaus et al., 1991). Alkaloid concentrations are greater in the sheath of the leaf compared with the blades of the plant as a result of greater mycelia mass in sheaths than in blades and because colonization of the endophyte in the blades does not always occur and depends on the timing that hyphae enter the developing leaf (Christensen et al., 2001, 2002). Concentrations of ergot alkaloids are greatest in the late spring after plants have developed seedheads, decrease during the summer, then increase again in fall (Nihsen et al., 2004).

Ergot alkaloids are structurally similar to the ergoline ring of the biogenic amines serotonin, dopamine, norepinephrine, and epinephrine, causing the ergot alkaloids to function in the biological system as these biogenic amines (Berde, 1980). Because of the similarity of chemical structures, these alkaloids can bind to the biogenic amine receptors and trigger effects such as vasoconstriction and reduced serum and pituitary gland prolactin concentrations (Hurley et al., 1980; Schillo et al., 1988).

Ergot alkaloids are absorbed in the gastrointestinal epithelia through either passive or active/facilitated diffusion (Strickland et al., 2011). Ergopeptine alkaloids are acidic, creating the assumption that they would not be absorbed via the abomasum 
(Eckert et al., 1978) and would be limited to absorption within the small intestine in non-ruminants (Rothlin, 1933) and the fore stomach and intestine in ruminants (Hill et al., 2001). Because the environment within the rumen and intestines are not acidic, they do not possess a mucosal layer, allowing absorption of ergopeptine alkaloids to occur across the gastrointestinal epithelia via the lymphatic system (Eckert et al., 1978). The alkaloids are then transported to the systemic circulation through the thoracic duct and subclavian vein or the mesenteric vein, which carries them through the portal system and liver.

Hill et al. (2001) reported that alkaloid absorption occurred across all ruminal, reticular, and omasal walls by way of active transport. Eckert et al. (1978) showed that differences in gender, age, health, status of production and nutrition, or whether absorption modifiers were present can all affect alkaloid absorption. After exposure, ergot alkaloids can be found within several different tissues in the mammalian body. Ninety minutes after lysergic acid was administered intravenously to cats, its derivatives were found in the plasma, lungs, liver, kidney, brain, intestines, heart, and fat (Eckert et al., 1978). In rats, ergopeptine concentration was less in the blood than in all other tissues except the brain. Ergotamine, an ergopeptine produced by claviceps fungi and not the epicloë endophyte, is not as water-soluble compared with lysergic acid, so the increase in concentration in the blood may have been due to ergot alkaloid bioaccumulation (Eckert et al., 1978). Ergot alkaloids have been reported in the subcutaneous adipose tissues of cattle in very small amounts $(2.81 \mu \mathrm{g} / \mathrm{kg})$ after the cattle were removed from pasture containing endophyte-infected tall fescue (Realini et al., 2005). After cattle were exposed to ergot-contaminated concentrate, Schumann et 
al. (2009) was unable to detect ergot alkaloid residues in blood or milk. Residues were also absent from Holstein bulls exposed to ergot alkaloids in the muscle, serum, fat, liver, kidney, urine, or bile samples (Schumann et al., 2007).

\section{NEGATIVE EFFECTS OF ENDOPHYTE-INFECTED TALL FESCUE ON GRAZING ANIMAL PRODUCTION}

\section{Tall Fescue Toxicosis}

Fescue toxicosis is a condition caused by the ingestion of ergot alkaloids. Ingestion of the alkaloids causes persistent vasoconstriction in cattle (Rhodes et al.,

1991; Aiken et al., 2007), sheep (Rhodes et al., 1991), goats (Aiken and Flythe, 2014), and horses (McDowell et al., 2013), which reduces blood flow to peripheral tissues. Strickland et al. (2011) estimated that the combined losses of all grazing animal industries that could be affected by endophyte-infected tall fescue exceeds $\$ 1$ billion annually, making tall fescue toxicosis the largest animal health-related production cost for the livestock industry in the United States.

Signs of fescue toxicosis are the retention of rough hair coats, increased body temperatures, labored breathing, and a general unthrifty appearance in animals grazing endophyte-infected tall fescue (Hoveland et al., 1983; Hemken et al., 1984). Toxicosis symptoms that are not visible can be more harmful to the animal, including vasoconstriction, resulting in the restriction of blood flow to the extremities; elevated core body temperatures; increased respiration and an increase in heart rate (Roberts et al., 2004). Core body temperatures elevate when blood flow is restricted to the periphery of the animal. Ergot alkaloids bind adrenergic and serotonin receptors, 
causing vasoconstriction of blood flow through the peripheral vasculature, reducing the ability of the animal to dissipate heat from the interior to the skin (Oliver, 2005). In steers fed a diet with $0.52 \mathrm{mg}$ ergovaline/kg DM, Rhodes et al. (1991) showed reduced blood flow to the skin tissue over the ribs by $50 \%$ compared with steers fed a diet with a concentration of $<0.05 \mathrm{mg}$ ergovaline $\mathrm{kg}^{-1} \mathrm{DM}$.

Aiken et al. (2007) used color Doppler ultrasonography to show that heifers previously unexposed to toxic endophyte-infected tall fescue exhibited vasoconstriction within $27 \mathrm{~h}$ after being fed a diet consisting of $0.8 \mathrm{mg}$ ergovaline $\mathrm{kg}^{-1}$ DM. In another experiment, Aiken et al. (2009), fed heifers diets consisting of $0.4 \mathrm{mg}$ ergovaline/kg DM and observed vasoconstriction within 51 hours after exposure.

Myographs in biopsied veins from heifers that had not previously been exposed to ergot alkaloids showed that initial contraction of biopsied lateral saphenous veins occurred at concentrations of $10 \mathrm{n} M$ of either ergovaline or ergotamine in an in vitro study (Klotz et al.

2007). Two- to $3-\mathrm{mm}$ cross sections of the vein were exposed to the alkaloids ergovaline and ergotamine every 15 min after buffer was replaced, and contractile responses of the veins were similar for both alkaloids. The saphenous vein exposed to ergovaline did not relax and contractions were not reversed over 105-mins after repeated buffer replacement. The absence of a relaxation response of the saphenous vein after the buffer was added following exposure to ergovaline suggests a potential for bioaccumulation of ergot alkaloids in the vasculature of animals exposed to endophyteinfected tall fescue (Klotz et al., 2007). Klotz et al. (2008) subsequently exposed lateral saphenous veins to increasing doses of ergovaline, lysergic acid, and $\mathrm{N}$-acetylloline and 
evaluated contractile responses. Lysergic acid, a toxin produced by the endophyte in infected tall fescue, did not induce contractility until $100 \mu M$ exposure of the vein. Exposure to $\mathrm{N}$-acetylloline did not elicit a contractile response to the magnitude of lysergic acid or ergovaline. When exposed to ergovaline at a concentration of $10 \mathrm{nM}$, contraction was apparent and continued to increase as the potency of ergovaline was increased to a maximum of $100 \mu M$ Klotz et al. (2010) reported similar contractile responses were achieved when saphenous veins were exposed to similar concentrations of the ergopeptines ergonovine, ergocryptine, ergocristine, and ergocornine, indicating that ergovaline is the most potent vasoconstrictor, but all ergopeptines contribute to vasoconstriction.

\section{Animal Performance}

Animals experiencing fescue toxicosis generally have decreased performance, including low forage intake and low rate of gain (Strickland et al., 1993). Reduced intake from animals grazing endophyte-infected tall fescue could result in decreased animal performance (Schmidt et al., 1982). A linear relationship was observed between ADG and average percent endophyte in Kentucky-31 tall fescue treatments (Stuedemann et al., 1986), with a $0.045 \mathrm{~kg} / \mathrm{d}$ depression in ADG with every $10 \%$ increase in endophyte-infection frequency in tall fescue pastures.

During June, cows grazing endophyte-infected tall fescue had similar organic matter intake compared with cows grazing endophyte-free tall fescue or orchardgrass (Peters et al. , 1992); however, in August, organic matter consumption was reduced in cows grazing endophyte- infected tall fescue by $0.4 \%$ compared with cows not on 
infected pastures. Cows that grazed toxic tall fescue had reduced weight in the early part of the grazing season, even with similarities in organic matter consumption compared to cows on nontoxic fescue that gained weight. Cattle offered increasing amounts of endophyte-infected tall fescue had a linear decrease in DM consumption (Goetsch et al., 1987).

Ruminal kinetics can be altered in response to exposure to toxic endophyteinfected tall fescue. Hannah et al. (1990) reported decreased ruminal fiber digestion after sheep were fed diets high in ergovaline, and had reduced ruminal fiber digestion as a result of increased ruminal fluid and rate of outflow. Dry matter intake and digestibility was reduced in steers fed endophyte-infected tall fescue in $20^{\circ} \mathrm{C}$ or $32^{\circ} \mathrm{C}$ environments compared with steers being fed endophyte-free fescue in the same environmental conditions (Aldrich et al., 1993).

Ergot alkaloids can alter the function of the hypothalamus, pituitary, and pineal glands (Hurley et al., 1980). Hurley et al. (1980) observed that most animals consuming endophyte- infected tall fescue have reduced prolactin concentrations. Prolactin release from the anterior pituitary is inhibited after consumption of endophyte-infected tall fescue (Sheeler et al., 1985). Ergot alkaloids contain an ergoline ring structure, similar to that of the hormone dopamine, which causes ergot alkaloids to mimic dopamine on inhibiting prolactin secretion by the anterior pituitary gland (Sibley and Creese, 1983; Lamberts and McLeod, 1990). Compounds that antagonize dopamine activity increase circulating prolactin, helping to mitigate symptoms of fescue toxicosis (Rhodes et al., 1989). Schillo et al. (1988) reported reduced dopamine after exposure to ergot alkaloids, causing reduced activity of the 
dopaminergic neurons and reducing the concentration of prolactin.

An increase in dopamine and serotonin follows an increase in body temperature, and an increase in turnover without an increase in synthesis results in reduced dopamine, serotonin, and their metabolites, along with an impairment of the mechanism responsible for regulating prolactin secretion within the animal (Porter et al., 1990). Heldmaier and Lynch (1986) reported that an animal's ability to physiologically adapt to seasonal changes may be impaired with imbalances in prolactin secretion. Imbalanced prolactin concentrations may result in animals grazing endophyte-infected tall fescue because of the consumption of alkaloids produced by the fungus. The imbalance in prolactin may result in a long hair coat (Allain et al., 1981), contributing to reduced heat tolerance by cattle on endophyte-infected tall fescue during hot summer months. Elevated core body temperatures in cattle grazing toxic tall fescue are due to the inability to thermoregulate under stressful environments as a result of vasoconstriction (Hemken et al., 1984; McClanahan et al., 2008). Further, rough hair coats can exacerbate elevated core body temperatures from toxicosis by insulating internal temperatures and reducing the rate of sweating as air temperatures increase.

Cattle grazing endophyte-infected tall fescue are commonly observed to wallow in mud or stand in ponds, particularly during the mid-day when ambient temperatures are at their highest (Boman et al., 1973). This can interfere with grazing time, significantly reducing the amount of time an animal grazes, potentially adding to the negative effects on animal performance. In a study observing the effects of cattle grazing behavior on tall fescue with a high endophyte- infection Bond et al. (1984) 
found that animals grazing the highly infected fescue stayed in the shade 8 and $17 \%$ of the time they were observed, and grazed $20 \%$ less than cattle on pastures with low infection levels. Further, from the hours of 1200 to 1600, Stuedemann et al. (1985) found that cattle on highly infected fescue pastures grazed $5 \%$ to $21 \%$ of that time, while steers on low-endophyte pastures grazed $43 \%$ to $65 \%$ of that time. Cattle grazing toxic tall fescue tend to graze toxic tall fescue more frequently at night compared with cattle grazing non-toxic fescue or other forages (Paterson et al., 1995).

\section{Reproductive Performance}

Reproductive problems in animals grazing endophyte-infected tall fescue can also occur. This includes retained and thickened placenta (Gay et al., 1988), reduced conception rates, and difficulty during parturition (Monroe et al., 1988). Porter and Thompson (1992) attributed reduced birth weights of calves from cows on endophyteinfected pastures to reduced blood flow to the uterine areas paired with reduced intake during gestation. After grazing endophyte- infected tall fescue, progesterone levels, a hormone necessary for conception and maintenance of gestation, are reduced in serum in ewes (Burke et al., 2006), horses (Monroe et al., 1988), and heifers (Jones et al., 2003). After exposure to endophyte-infected tall fescue, weaned heifers had reduced progesterone concentrations while yearling heifers were not affected, indicating that age and stage of production play a role in the sensitivity and impact of alkaloids on biological functions (Mahmood et al., 1994). Conception rates of cows grazing toxic tall fescue were $41 \%$ lower than heifers grazing nontoxic tall fescue (Schmidt et al., 1986). Boling (1985) reported calving rates at $86 \%$ for cows grazing low endophyteinfected fescue verses $67 \%$ for those cows on high endophyte-infected pastures. In the 
Schmidt et al. (1986) experiment, only $33 \%$ of the cows calving for the first time were rebred if they were grazing highly infected pastures, whereas cattle grazing pastures with a low infection rate had a $93 \%$ rate of rebreeding. In that study, for every $10 \%$ increase in infection rate, conception rates decreased by $3.5 \%$.

Low serum prolactin, resulting in reduced milk yield along with suppression of the immune system, also occurs after consumption of endophyte-infected fescue (Strickland et al., 1993). With a decrease in milk production and reduced intake during gestation, low calf weaning weight can result (Keltner et al., 1988).

Schuenemann et al. (2005a) deduced that reduced fertilization potential may occur in bulls exposed to endophyte-infected tall fescue after finding reduced cleavage rates of embryos fertilized by in vitro fertilization from bulls fed ergotamine tartrate compared with bulls on a control diet. In a similar study by Schuenemann et al. (2005b), in vitro fertilized embryos from cows fertilized with semen from bulls grazing nontoxic MaxQ tall fescue had greater cleavage rates compared to embryos fertilized with semen from bulls grazing toxic Kentucky-31 tall fescue. Jones et al. (2004) found that bulls fed a toxic tall fescue diet had lower scrotal circumference and greater scrotal temperature compared with bulls fed a control diet with no toxic endophytes. Brahman-influenced bulls on endophyte-infected tall fescue pastures had an overall reduction in serum prolactin concentrations compared with bull grazing novel endophyte tall fescue, and reduced motile sperm in July and August (Looper et al., 2009). 


\section{Fat Necrosis}

Altered lipid metabolism, leading to liptomatosis, or fat necrosis, occurs after long-term consumption of endophyte-infected tall fescue (Wilkinson et al., 1983). A mass of necrotic fat caused by premature death of cells can result in reduced reproductive capacity, as the necrotic tissue commonly accumulates around the abdominal cavity of the animal. Stuedemann et al. (1985) deduced that fat necrosis commonly occurs in cattle grazing endophyte-infected tall fescue that received high levels of nitrogen fertilizer.

Realini et al. (2005) showed that after they are metabolized in the liver, alkaloids can be retained and stored in fat tissue and the toxins can be released for months, causing the animals to show signs of toxicosis long after they have been removed from infected pasture. This preservation of alkaloids in fat tissue could explain why necrosis of fat occurs, as well as why animals show symptoms of toxicosis into the summer months and in the feed yard (Lusby et al., 1990; Duckett et al., 2001).

\section{Fescue Foot}

Another potential negative side effect of animals grazing endophyte-infected tall fescue for a prolonged time is the possibility of the occurrence of "fescue foot," a condition where lameness occurs and hooves can slough off (Bush et al., 1979) as a result of vasoconstriction and decreased blood flow to the extremities (Garner and Cornell, 1987). Other extremities may be lost as a result of reduced blood flow, including tips of ears and tails. In the early stages of fescue foot, a red color can be observed around the coronary band of the hoof. Jacobson et al. (1970) reported signs of 
fescue foot as early as 25 days after the start of grazing.

\section{MITIGATING FESCUE TOXICOSIS}

\section{Pasture Renovation}

Several strategies can be employed to mitigate the effects of the toxic alkaloid causing fescue toxicosis. One mitigation strategy includes renovating pastures containing toxic endophyte-infected tall fescue with other tall fescue varieties that either do not contain an endophyte or contain a novel endophyte that does not produce the toxic ergot alkaloids. A simple and inexpensive way to kill the living endophyte within the tall fescue seed is to store the seed for one year in a non-air conditioned, moderate to high ambient temperature, dry area (Rolston and Young, 2009). However, with complete removal of the endophyte comes diminished plant persistence as a result of the absence of the mutualistic relationship between the endophyte and the fescue. Grazing studies comparing performance between cattle grazing toxic endophyte infected and non-infected tall fescue have found greater weight gain in steers and normal milk production and conception rates in cows that grazed non-infected tall fescue (Hoveland, 1993). Higher body condition scores for cows and greater average daily gains for calves grazing novel endophyte fescue versus pairs on endophyteinfected fescue (Watson et al., 2004). In that study, birth weights at calving were greater for calves whose dams were grazing nontoxic novel endophyte pastures than those grazing toxic wild-type endophyte. Bouton et al. (1993) demonstrated that endophyte-free tall fescue is unable to withstand the grazing pressure or drought that endophyte-infected fescue withstands, resulting in reduced forage yield and possibly 
encouraging the weed encroachment as the fescue stand is lost.

Endophyte strains that live and thrive in tall fescue have been identified that produce the lolines and peramine alkaloids that impart the plant with tolerances to stress, but do not produce the ergot alkaloids that are toxic to animals (Aiken and Strickland, 2013). AgResearch Ltd. of Ruakura, New Zealand first patented a Neotyphodium coenphialum endophyte strain that does not produce ergot alkaloids (Latch et al., 2000) and following mob grazing trials to evaluate the greatest survival rates, the variety Jesup-MaxQ was released (Bouton et al., 2002). Novel endophyte tall fescue varieties provide some of the desirable hardiness and persistence through adverse environmental conditions that toxic endophyte-infected tall fescue possesses as a result of the plant-endophyte symbiosis without the detrimental effects to the livestock.

\section{Mechanical Removal of Emerged Seedheads}

The seedheads of endophyte-infected tall fescue can contain up to three times greater concentration of ergovaline than the rest of the plant (Rottinghaus et al., 1991). By removing the seeds with a mower, the incidence of toxicosis symptoms could be greatly reduced by eliminating the main source for the majority of the ergovaline consumption.

\section{Grazing Management}

Implementing grazing management strategies that help to eliminate the incidence of the emergence of seedheads could also help to alleviate seedhead consumption (Rottinghaus et al., 1991). At three different stocking rates, Bransby et 
al. (1988) determined ADG were improved or remained the same as stocking densities increased due to eliminating the presence of toxic seedheads. These daily gains were comparable to animal performance on endophyte-free pastures. Heavier stocking rates also discourage selectivity of forages and increase the total portion of the plant consumed, leading to reduced occurrence of seedheads in the pasture.

Belesky and Hill (1996) showed that, although older fescue leaves have the lowest alkaloid concentrations, repeated intensive defoliation of leaves reduced the concentration of non- structural carbohydrates, which, in turn, limited alkaloid production within the leaves. This could likely be the cause of the increased ADG with increased stocking rates on tall fescue in a study by Bransby et al. (1988). Because of the frequent defoliation, plant carbohydrate levels were reduced by maintaining the fescue canopy at a young vegetative production stage, causing decreased production of ergot alkaloids and in turn causing increased animal performance as stocking rate increased. The amount of $\mathrm{N}$ nutrition and readilyavailable energy within the plant is a function of the rate of alkaloid production (Belesky et al., 1988). Therefore, with increased defoliation due to a greater stocking rate, carbohydrate and $\mathrm{N}$ stores are depleted, limiting the rate of alkaloid production and ultimately reducing dietary concentration of ergot alkaloids.

Steroidal implants can offer additive benefits in animal performance when cattle are on pasture; however, average daily gains did not differ in cattle that were not implanted with steroidal implants as stocking densities increased. However, in implanted cattle, as stocking rates increased, $\mathrm{ADG}$ decreased linearly as forage availability decreased, indicating reduced efficacy of the implants in cattle grazed on 
toxic tall fescue with reduced forage availability and therefore, nutrient supply (Aiken et al., 2006).

Livestock producers could also rotate their grazing animals from toxic tall fescue during hot summer months and onto warm-season grass pastures to avoid periods when high alkaloid concentrations are present and animals are most vulnerable to severe heat stress (Aiken and Strickland, 2013). Roger et al. (2011) reported that as reproductive development of endophyte- infected tall fescue advances into summer, ergot alkaloid concentrations in whole plants increase. Hot summer months are when cattle are most susceptible to "summer slump" and are most at risk for severe heat stress coupled with a decline in performance. By removing them from toxic pastures the effects of toxicosis can be alleviated (Aiken and Strickland, 2013). Warm-season grasses also can provide the nutrients needed to increase the animals' plane of nutrition by grazing during active growth of warm-season grasses when there is a decline in the growth of tall fescue (Robert and Andrae, 2004).

Grazing animals tend to selectively and actively graze the seedheads of tall fescue (Aiken et al., 1993; Goff et al., 2012) and because the ergot alkaloid concentrations are greater in the seedhead than any other part of the fescue plant (Rottinghaus et al., 1991), letting livestock graze while it is in the reproductive stage of production could increase the incidence of fescue toxicosis among the animals. Management to reduce the development of reproductive tissues of tall fescue, such as rotational grazing strategies, high stocking rate or mowing, may be an appropriate measure to help to reduce the occurrence of fescue toxicosis in grazing animals. 


\section{Dilution with Legumes}

Interseeding legumes into a toxic endophyte-infected pasture can dilute ergot alkaloids in the diets of ruminants and has been shown to increase animal performance (McMurphy et al., 1990). Seath et al. (1954) showed that dairy cows grazing fescueclover pastures had greater milk production than cows grazing endophyte-infected tall fescue pastures. Clover has been shown to improve steer ADG by $25 \%$ to $50 \%$ in steers grazing fescue-clover pastures over those grazing monocultures of endophyteinfected fescue (Hoveland et al., 1999). Gay et al. (1988) reported that cow herds grazing toxic fescue pastures interseeded with clovers can have reduced weight loss, improved conception rates, and increased calf weaning weights. Although careful management of legumes is needed to maintain persistence, their benefits to animal performance justify the additional management inputs. It is difficult to determine if the benefit of clover interseeded into toxic tall fescue is due to dilution of ergot alkaloids, or improved nutrition; however, it is likely a combination of both.

\section{Feeding Concentrates or Co-Product Feeds}

Providing supplements to cattle grazing toxic tall fescue pastures can help mitigate the effects of the endophyte. Steers fed soybean hulls at a rate of $2.3 \mathrm{~kg} / \mathrm{steer} / \mathrm{d}$ while grazing toxic endophyte-infected tall fescue had sleeker hair coats, greater serum prolactin concentrations, and a 32\% greater ADG compared with control steers without the soybean hull treatment (Carter et al., 2010). Steers fed corn or corn gluten on endophyte-infected tall fescue pasture during August at 1\% of their body weight had decreased forage organic matter while there was an increase in total OM consumption (Hannah et al., 1989). Organic matter intake of endophyte- infected tall fescue green 
chop was decreased by $14 \%$ in a study by Richards et al. (2006) when cattle were supplemented with soybean hulls at $0.60 \%$ of their BW compared with steers consuming endophyte-infected fescue green chop alone. When lactating cows were supplemented with blood meal while grazing endophyte-infected tall fescue, an increase in $18.4 \mathrm{~kg}$ was gained compared with cows grazing toxic tall fescue alone (Forcherio et al., 1993). However, the addition of the ruminally undegradable protein did not increase calf performance.

\section{Genetic Improvement in Grazing Animals}

There is a difference in the symptomology of fescue toxicosis between breeds of beef cattle. In a study by Brown et al. (1992) in which both Bos indicus (Brahman) and Bos taurus (Angus) cows were grazing endophyte-infected tall fescue, Angus cows had less milk production than the Brahman cows. When comparing Senepol and Brahman steers to Hereford steer performance with all breeds grazing endophyteinfected tall fescue, Senepol and Brahman steers had greater ADG, lower respiration rates, and decreased use of shade compared with Hereford steers in summer months (Browning et al., 2000; Browning, 2004). It appears that tropical/subtropical breeds of cattle are better adapted to alleviate the heat challenge imposed by alkaloid-induced vasoconstriction. An environmental interaction with genotype or the breed differences in heat tolerance could be the cause of the differences in response of the different breeds to grazing toxic tall fescue (Waller, 2009). 


\section{Chemical Suppression of Tall Fescue Seedhead Emergence}

Chemical seedhead suppression in toxic endophyte-infected tall fescue was first studied in the herbicide mefluidide, a plant growth regulator, that delays maturity in early spring treated fescue (Sheaffer and Marten, 1986; Turner et al., 1990). Treating the fescue with mefluidide maintained desirable forage quality into the summer (Sheaffer and Marten, 1986) and in a 168-d grazing trial, steers grazing treated pastures experienced a $17 \mathrm{~kg}$ increase in weight gain compared with steers on untreated pastures, and had a 47\% greater organic matter intake in July (Turner et al., 1990). Mefluidide was never licensed for use on grazed pastures, restricting its use for the suppression of seedhead emergence in tall fescue (Aiken and Strickland, 2013).

The broad-spectrum herbicide, Chaparral (Dow AgroSciences; Indianapolis, IN), contains aminopyralid (2-pyridine carboxylic acid, 4-amino-3,6-dichloro-) and metsulfuron- methyl \{Methyl 2-[[[[(4-methoxyl-6-methyl-1,3,5-triazin-2-yl)amino]carbonyl]amino]sulfonyl] benzoate and is licensed for control of broad-leaf weeds on rangeland and permanent grass pastures. The metsulfuron-methyl component of Chaparral inhibits reproductive growth stages by suppressing seedhead emergence in tall fescue and allowing the grass to remain in a vegetative stage for the duration of the growing season. Because the seed of endophyte-infected tall fescue has a six-fold greater concentration of ergovaline, alleviating seedhead emergence could help reduce the incidence of fescue toxicosis by eliminating the seedheads that cattle selectively graze (Goff et al., 2012), leading to increased animal performance (Aiken et al., 2012). 
Aiken et al. (2012) showed that in lightly-grazed mixed cool-season grass pastures that were either treated or not treated with Chaparral, the incidence of seedheads were nearly 10 -fold greater in untreated pastures than those treated with Chaparral. Although there was a decline in seedhead emergence, there was reduced forage mass. There was no difference in the ergovaline concentrations of vegetative growth between treatments; however, forage from the treated pastures averaged $14.4 \%$ crude protein while untreated pastures averaged $11.6 \% \mathrm{CP}$, and in vitro dry matter digestibility (IVDMD) was 6.9 percentage units greater in treated pastures compared with untreated pastures (Aiken et al., 2012). Forage from the treated pastures had greater water-soluble carbohydrate (WSC) content compared with forage from untreated pastures. Aiken et al. (2012) further reported that steers grazing Chaparraltreated pastures exhibited increased ADG by 39\% compared with cattle grazing untreated pastures and had $97 \%$ greater serum prolactin concentrations.

Goff et al. (2012) evaluated plant and animal performance in endophyte-free tall fescue with and without Chaparral application at low and moderate grazing intensity. The objective of this study was to determine the effect of endophyte-free fescue maintained at a vegetative state throughout the grazing season on animal and pasture responses that was independent of alleviation of toxic seed heads. Untreated pastures had ten-fold greater seedhead emergence compared to treated pastures. In vitro dry matter digestibility and CP was greater in Chaparral- treated pastures compared with untreated (14.2\% and 9.9\%, respectively) and WSC tended to be greater in treated pastures (Goff et al., 2012). An increase in ADG of 45\% in steers grazing herbicidetreated pastures with low and moderate stocking densities was found, which could be 
areflection on the increased forage quality available to the grazing animals on Chaparral-treated pastures (Goff et al., 2012).

Aiken et al., (2012) reported that cattle in mixed tall fescue-Kentucky bluegrass (Poa pratensis L.) pastures preferentially grazed tall fescue over the earlier-maturing bluegrass, which went into reproductive stages of growth 2 to 3 weeks earlier than the untreated tall fescue (Ball et al., 2007). Consumption of bluegrass was minimal and the pasture canopies indicated that the fescue was preferentially grazed over the bluegrass, which likely contributed to less tall fescue in the aboveground herbage mass measured near the conclusion of the study (Aiken et al., 2012).

Lack of increase in bluegrass within the pastures from year 1 to the second year of the study indicates there was no tall fescue stand loss as a result of herbicide application. The application of Chaparral to pastures containing endophyte-infected tall fescue could help to alleviate the severity of the negative symptoms of fescue toxicosis, as well as lead to an improvement in forage quality as a result of the prolonged vegetative stages of growth occurring after the elimination of seedhead emergence.

\section{GRAZING MANAGEMENT}

Nutrient intake and performance of animals grazing on pasture is interrelated and altered by herbage intake as a result of pasture conditions and canopy characteristics, such as leaf-to- stem ratio, canopy height, and forage maturity (Hodgson, 1990). Dry matter intake of grazing animals can be sensitive to pasture characteristics. Animal performance primarily depends on amount of forage available and forage maturity and quality, as well as its distribution within the pasture (Hodgson, 
1990). Grazing can be managed in a variety of ways to optimize animal and pasture productivity, depending on the operation's production goals.

\section{Continuous Grazing}

Pastures that are continuously grazed have animals maintained on a single pasture unit for the duration of an entire grazing season (Ball et al., 2007).

Continuously grazed pastures allow grazing animals to have a high rate of selectivity for higher quality forage, lest it is stocked at the correct rate. In continuously grazed systems, stocking rate can be set with a fixed number or may be adjusted to fit the supply of forage over the grazing season (Ball et al., 2007). At fixed stocking rates, some forage may be over-grazed while others may be under-grazed (i.e., spot-grazing), or feed resources may become limiting as the grazing season progresses, potentially leading to a decline in animal performance and pasture productivity (Ball et al., 2007). By adjusting stocking rates according to feed availability, animal selectivity of forages can be maintained to ensure optimum animal performance while ensuring the production of grass tillers to maintain pasture stability and production over time (Ball et al., 2007).

A study by Hull et al. (1967) found that continuous grazing provided increased gain per animal day per hectare and energy gain per hectare than for animals on rotationally grazed pastures. For warm-season forages, there was no difference in stocking rates between continuous and rotationally grazed pastures in an experiment by Aiken (1998), and daily animal weight gain did not differ as a result of grazing method, (i.e., continuous, and low and high intensity grazing pastures). At light 
stocking rates, Kee et al. (1991) reported greater average daily gains in cattle in continuously grazed treatments, but this advantage decreased with increasing stocking rates.

\section{Rotational Grazing}

Rotational grazing refers to a grazing system in which animals are rotated through paddocks within a larger, subdivided pasture, allowing for rest periods of each paddock following the grazing period (Ball et al., 2007). The goal of a rotational grazing system is to provide the animal with a high-quality diet by allowing the top, leafy portion of the forage to be grazed while maintaining tall stubble post-grazing to allow for enhanced regrowth (Dalrymple, 1996). Grazing periods can range from a few hours to a few days in each paddock, depending on forage availability, stocking rate, and paddock size. In a rotational system, herbage intake and animal performance are related to allowance of forage dry matter (Hodgson, 1990). Optimal stubble height for rotational paddocks is $10 \mathrm{~cm}$ (Hodgson, 1990). Although studies show that rotationally grazed pastures usually offer no improvement in individual animal performance from either low-intensive or high-intensive rotational systems, this grazing system encourages uniform utilization of the forage available in the pasture and can lead to an increase of carrying capacity (Aiken, 1998; Ball et al., 2007). Hull et al. (1967) reported that an improvement in stocking rates resulted in a greater increase in gain per unit of land area. A greater number of animal grazing days per hectare were also noted on rotational grazing treatments. A study by Aiken (1998) showed an increased stocking rate on cool-season pastures using a 3-paddock and 11-paddock rotational system versus a continuously grazed system, as well as a $40 \%$ increase in steer gain per 
acre on cool-season forages as a result of an increased carrying capacity.

Numerically greater ADG were achieved in combination with greater stocking rates in rotationally grazed pastures. Quality of diet in rotationally grazed pastures did not differ from diet quality of continuously grazed pastures, although carrying capacity was increased in rotationally grazed pastures in a study by Walker et al. (1989).

Along with increased forage utilization and a potential increase in carrying capacity, rotational grazing can also allow pasture plants that are sensitive to continuous grazing an opportunity for better persistence and productivity, as well as minimizing the amount of forage that is wasted by trampling and becoming overmature (Ball et al., 2007). Hull et al. (1967) found that with heavy stocking rates, rotational grazing can increase weight gain per hectare and pasture carrying capacities on cool-season grass and legume pastures. Forage variety that is being grazed also greatly affects the efficacy of rotational grazing because of differences in nutritive values, persistence, and productivity.

Shifts in botanical composition of forages in a grazing area can occur as a result of grazing management. Hull et al. (1967) reported reduced legumes and a shift towards predominantly grasses in rotationally grazed pastures compared with continuously grazed pastures. In their continuous pastures, the greatest proportion of legumes was maintained. This could be a result of increased forage utilization and reduced forage selection by grazing animals commonly found in rotationally grazed pastures. 


\section{Stocking Densities}

Studies have shown that stocking rates frequently interact with method of grazing as a result of its effect on forage quantity and quality (Bransby, 1991; Kee et al., 1991). Heavy stocking is more favorable for rotational grazing methods, while lighter stocking rates that allow forage accumulation are more favorable for continuously grazed pastures. Hull et al. (1967) showed that a rotational grazing system with heavy stocking had greater weight gain per hectare than medium stocking on rotational and continuously grazed pastures, with $669 \mathrm{~kg}$ in heavy stocked rotational and 547 and 591 in medium stocked rotational and heavy continuous, respectively.

\section{CARRY-OVER OF ALKALOIDS IN THE ANIMAL}

Although growing animals just removed from endophyte-infected tall fescue appear unthrifty, often causing their sale prices to be discounted, compensatory gains often occur after animals enter a feedyard (Cole et al., 1987; Coffey et al., 1990). Cole et al. (1987) reported that gains were most rapid during the initial seven weeks of the feeding phase after cattle were removed from endophyte-infected tall fescue pastures, indicating that consuming the endophyte did not have a permanently negative effect on animal growth rate. Cattle previously grazed on endophyte-infected fescue in the summer gained $1.40 \mathrm{~kg} / \mathrm{d}$ compared with cattle that previously grazed endophyte-free tall fescue $(1.27 \mathrm{~kg} / \mathrm{d})$ after being placed on feed in the finishing phase (Forcherio et al., 1992).

A 2-year feeding study by Aiken et al. (2013) showed carry-over effects of fescue toxicosis in steers during the feeding phase after they were removed from 
endophyte-infected tall fescue. Rectal temperatures, after entry into the feedyard, declined linearly in steers that were previously on toxic fescue, but did not change in cattle that were previously on endophyte-free pastures; rectal temperatures were similar among treatments by day 30 of the feeding period.

Doppler ultrasound measures of the caudal artery showed luminal areas of steers that had grazed endophyte-free fescue were greater through the duration of the feeding trial compared with the steers previously grazed on endophyte-infected pastures; however, luminal areas of endophyte- infected cattle increased linearly during study (Aiken et al., 2013). At the start of the feeding period, serum prolactin concentrations were nearly double in cattle removed from endophyte-free pastures; however, a curvilinear increase was found in serum prolactin concentrations of steers in endophyte-infected treatment, and by day 15 in year 1 and day 10 in year 2, the serum prolactin concentrations of the endophyte-infected steers did not differ from endophytefree steers (Aiken et al., 2013). Because this was only a 30-day feeding trial observing the carry-over effects of fescue toxicosis within the animal, longer trials are needed to fully observe the rate of clearance of the alkaloid and the long-term effects the endophyte-infected fescue has on the grazing animal.

Copyright $(\mathcal{C}$ Jessica A. Williamson 2015 


\section{CHAPTER III: Materials and Methods}

This experiment was conducted for two grazing seasons at the University of Kentucky C. Oran Little Animal Research Center ( $38^{\circ} 5^{\prime}$ N, $84^{\circ} 44^{\prime}$ W). Soil types in the pastures were a McAfee silt loam (Fine, mixed, active, mesic Mollic Hapludalfs) and a Maury-Bluegrass silt loam complex (Fine, mixed, active, mesic Typic Paleudalfs). Crossbred, predominantly Angus, steers were used in 2013 and heifers, predominantly Angus, were used in 2014. Cattle for both grazing years were approximately 8 to 10 months old at the start of the grazing study. The experiment protocol was reviewed and approved by the University of Kentucky Institutional Animal Care and Use Committee (\#2013-1075). The research farm did not possess a weather station, so a National Weather Service Station, located approximately $13.5 \mathrm{~km}$ from the experiment location, was used to monitor regional air temperatures and precipitation.

\section{Experiment Design, Grazing, and Pasture Management}

Rotational or continuous grazing treatments were assigned to six, 3.0-ha pastures of mixed, cool-season grass (predominately toxic endophyte-infected, tall fescue-bluegrass mix) as a randomized complete block design to account for different soil types and topography. Three replications were used in 2013, and two replications were used in 2014 because there were fewer available calves for this grazing season. Rotationally grazed pastures were divided into four paddocks of equal area ( 0.75 ha) to provide a 28 - $\mathrm{d}$ rotation ( $7 \mathrm{~d}$ of grazing and $21 \mathrm{~d}$ rest periods). All treatments were sprayed with Chaparral $^{\mathrm{TM}}$ herbicide at a rate of $86.8 \mathrm{~g}$ a.i. (aminopyralid and 
metsulfuron) ha ${ }^{-1}$ on 8 March, 2013 (Year 1) and 1 May, 2014 (Year 2). Application was delayed in 2014 because of the lateness in initiating grazing and to accumulate forage and minimize a lag in growth following Chaparral application - as was observed with on-farm demonstrations in 2013. All pastures were fertilized with polycoated urea (ESN, Agrium Inc., Calgary, Alberta) to provide $62 \mathrm{~kg} \mathrm{~N} \mathrm{ha}^{-1}$ on 28 March in 2013 and 15 April in 2014.

A variable stocking rate was used with six "tester" animals assigned to each pasture for the duration of the study using put-and-take stocking (Mott and Lucas, 1953 ) to target an average disk meter height for each pasture. A total of thirty-six crossbred steers (initial BW: $356 \pm 33.90 \mathrm{~kg} ; 2013$ ) and 24 heifers (initial BW: $254 \pm$ $19.34 \mathrm{~kg} ; 2014)$ were used as "testers" that were blocked by BW for random assignment to pastures such that mean BW was similar across pastures. "Grazer" animals were added and removed throughout to maintain a post-graze compressed pasture height of 4 to $6 \mathrm{~cm}$ in rotationally stocked pastures and a mean compressed pasture height in continuously stocked pastures that were approximately the midpoint between pre- and post-grazed compressed heights of rotationally stocked pastured. Adjustments of stocking rates were made, if needed, immediately following measurements of disk meter height (DMH). Put-and-take calves were of similar breeding and body weight as testers.

\section{Pasture Measurements}

Forage mass was estimated by a rising plate disk meter at 2-wk intervals on days that rotationally grazed calves were moved (Bransby et al., 1977). Fifty random 
locations within each continuously grazed pasture, and 50 random locations each from pre- and post-grazed rotational pastures were used. Samples were dried at $60^{\circ} \mathrm{C}$ for $48 \mathrm{~h}$ in a forced-air oven. Samples for developing calibration equations to estimate forage mass from mean DMH for each pasture were collected by clipping forage below the disk meter plate to the soil surface at five random locations within each pasture twice during the grazing season both years; 29 May and 2 July, 2013; 3 June and 22 July, 2014.

Percentage of endophyte-infection was measured using immunoblot test kits (Agrinostics Ltd. Co., Watkinsville, GA) and was determined from single tillers randomly selected from 25 fescue plants within each pasture and clipped at the crown on 6 June 2013. Species frequency of herbage within the canopy was determined using point transects ( $n=$ between 500 and 600 points per pasture each year) at the conclusion of grazing cycles two and three in 2013 and before initiation of the study and at the conclusion of each grazing cycle in 2014. Prior to the start of the study in 2013, a double-sampling technique described by Ortega-Santos et al. (1992) for botanical composition was done, but methods were changed due to excessive error in estimating forage species in the complex mixture with an intertwining of leaf blades of similar color and structure. Pastures were primarily endophyte-infected tall fescue, Kentucky bluegrass, orchardgrass, and other species of cool-season forage grasses. A 50-m transect (tape) was placed on top of the canopy at 10 (2013) and 12 (2014) randomly chosen sites within each pasture.

Herbage of the forage species closest to each of the point that were 1.0-m-apart was recorded to determine an estimated percentage of occurrences for each forage species 
within the pasture. Tall fescue crowns were counted within a $0.25 \mathrm{~m}^{2}$ quadrat at 20 random locations within each pasture prior to the start and after terminating the study each year to determine if there were losses of fescue.

Five, $0.25 \mathrm{~m}^{2}$ quadrat samples were clipped to a 2.5 -cm height from each pasture at 2-wk intervals from continuous, pre-graze rotational, and post-graze rotational pastures. Quadrat samples were dried at $60^{\circ} \mathrm{C}$ for $48 \mathrm{~h}$ in a forced-air oven, ground to pass through a 2-mm screen in a Wiley mill, and analyzed for forage nutritive values; crude protein (CP), water soluble carbohydrates (WSC), acid detergent fiber (ADF), neutral detergent fiber (NDF), and in vitro digestible dry matter (IVDDM).

A Leco FP-215 N Analyzer (Leco Corp., St. Joseph, MI) was used to determine $\mathrm{N}$ in oven-dried quadrat samples (crude protein $[\mathrm{CP}]=\% \mathrm{~N} \times 6.25$ ). The ANKOM Daisy II Incubator was used to determine in vitro digestible dry matter (IVDDM) by following procedures for estimating true digestibility (ANKOM Technology, 2005) using the method described by Vogel et al. (1999). Neutral detergent fiber and ADF were analyzed using an ANKOM fiber digester as a modification to procedures of Goehring and Van Soest (1970). Water-soluble carbohydrates were determined by agitating $250 \mathrm{mg}$ of ground plant tissue in $25 \mathrm{~mL}$ of deionized water for $3 \mathrm{~h}$ at room temperature. Extracts were gravity-filtered and assayed for WSC with a potassium ferricyanide $\left[\mathrm{K}_{3} \mathrm{Fe}(\mathrm{CN})_{6}\right.$, Sigma-Aldrich, St. Louis, $\left.\mathrm{MO}\right]$ assay based on the protocols of Dairy One Forage Laboratory Services (Ithaca, NY; Dairy One, 2010). Extracts were hydrolyzed and WSC were determined using a model DU-800 spectrophotometer (Beckman Coulter Inc., Fullerton, CA) by the procedure described in Aiken et al. 
(2012).

At 2-wk intervals, whole tillers clipped from 25 random plants from within each pasture were freeze dried in a Botanique Model 18DX485A freeze drier (Botanique Preservation Co., Peoria, AZ) and ground to pass a 1-mm mesh (Cyclotec 1093 sample mill, FOSS North America, Eden Prairie, MN). These samples were analyzed for ergovaline and its stereoisomer, ergovalinine, using a high-performance liquid chromatography fluorescence procedure of Yates and Powell (1988) as modified by Carter et al. (2010).

Root samples for tall fescue were collected prior to the start of grazing and at termination of grazing for both seasons (22 April and 19 Aug, 2013; 7 May and 12 Aug, 2014). Eighteen to 20 plants were randomly selected from each pasture and excavated at a $15-$ to $20-\mathrm{cm}$ depth. The roots were clipped at the crown, washed to remove soil and debris, and frozen in a $-20^{\circ} \mathrm{C}$ freezer. Samples were subsequently freeze dried and ground to pass a 1-mm mesh screen, as described for whole tiller samples. Water-soluble carbohydrates (WSC) were analyzed using the same procedures as for the quadrat samples.

\section{Animal Management}

All animals were treated with Moxidectin (1 mL/10 kg BW pour-on; Cydectin, Fort Dodge Animal Health, Fort Dodge, IA) for internal and external parasites on the initial weigh date for both years. In 2013, steers were implanted with Synovex S (200 mg progesterone-20 mg estradiol; Fort Dodge Animal Health, Fort Dodge, IA); heifers were not implanted in 2014. 
Animals were provided free-choice mineral at all times during the grazing season (2013: Burkmann Mills, Danville, KY; zinc, 0.35\% min.; manganese, $0.2 \%$ min.; iron, $0.2 \%$ min.; copper, $0.03 \%$ min.; selenium, $0.009 \%$ max.; iodine, $0.007 \%$ min.; cobalt, 0.005\% min.; 2014: KNS, Lawrenceburg, KY; zinc, 0.4\% min.; manganese, 0.75\% min.; copper, $0.2 \%$ min.; selenium, $0.005 \%$ max.; iodine, $0.0125 \%$ min.; cobalt, $0.0015 \% \mathrm{~min})$.

Pastures were grazed from 16 April 2013 to 8 July 2013 (84 days of grazing) and from 20 May 2014 to 12 Aug 2014 (84 days of grazing); thus, pastures were grazed for a duration of $84 \mathrm{~d}$ in each grazing season. Cattle were fasted for 12- to 14-h and weighed on the initial and final days of grazing. The grazing experiment was delayed in Year 2 due to high cattle prices. The University of Kentucky's Animal and Food Sciences Department supplied growing heifers in 2014 to perform the study as a result of the unavailability of steers.

\section{Calculations and Statistical Analyses}

Stocking rates were adjusted to a $\mathrm{BW}$ basis $\left(\mathrm{kg} \mathrm{BW} \mathrm{ha}^{-1}\right)$ by multiplying the weighted average stocking rate [pasture carrying capacity divided by the number of days on pasture; Bransby et al., 1988 ] by the average BW of testers at the midpoint of the grazing season (average of the initial and final BW). Pasture carrying capacity (animal $\mathrm{d} \mathrm{ha}^{-1}$ ) is based on animal numbers and could not account for the disparity in BW between steers used in 2013 and heifers in 2014. Therefore, carrying capacity for each pasture was adjusted to animal units (AU

$=454 \mathrm{~kg}$ ) by dividing average tester weight at the midpoint by $454 \mathrm{~kg}$, and multiplying 
the carrying capacity by this as a conversion factor to provide $\mathrm{AU} \mathrm{d} \mathrm{ha} \mathrm{d}^{-1}$.

Data were analyzed as a randomized complete block design using PROC MIXED of SAS (Statistical Analysis Software, v. 9.3, SAS Institute Inc., Cary, NC) with three replications in 2013 and two replications in 2014. For the analyses of all responses, the experimental unit was pasture. Random effects were blocks and year $\mathrm{x}$ block interactions and fixed effects were treatment, year, and treatment $\mathrm{x}$ year interactions. Least square means were compared among treatments using the PDIFF option of SAS. Transect data for botanical composition were analyzed as repeated measures using the CS covariance structure. Degrees of freedom were adjusted using the Kenward-Roger method.

Copyright (C) Jessica A. Williamson 2015 


\section{CHAPTER IV: Results and Discussion}

Total monthly rainfall during both grazing seasons was greater than the 30 year average, with the exception of May and July, 2014 (Fig. 1). Air temperatures were generally cooler during the grazing seasons of both years, except May of 2013 which averaged $+0.22^{\circ} \mathrm{C}$ greater than the 30 -year mean and April, May, and June, 2014 which were $+1.00,+0.50$, and $+0.28^{\circ} \mathrm{C}$ greater than the 30 -year average, respectively (Table 1).

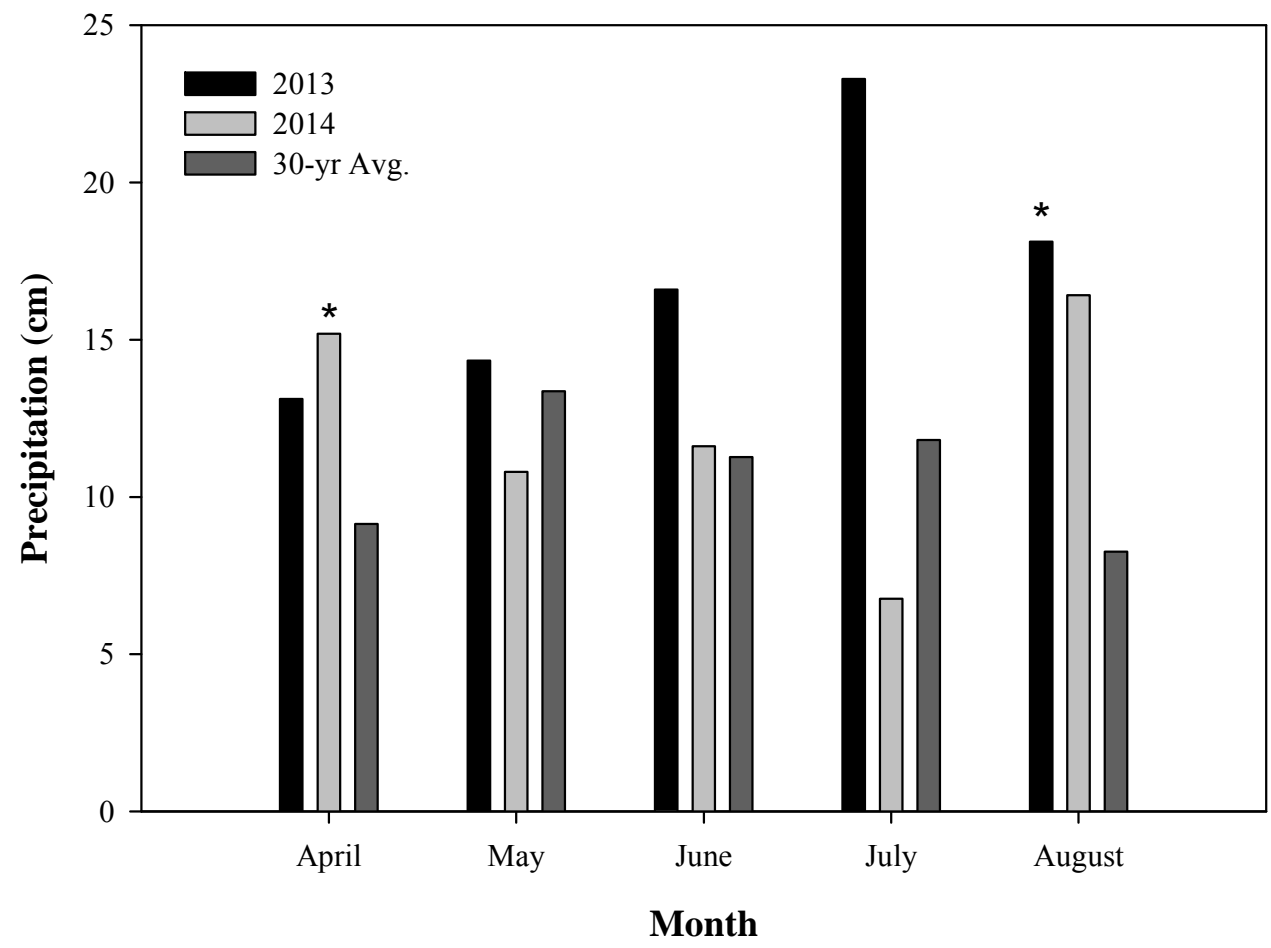

Figure 1. Total precipitation for the months of April to August during the grazing seasons in 2013 and 2014 and the 30-yr average. Asterisks $\left({ }^{*}\right)$ denote the grazing experiment was not conducted during that month that particular year of the study. Data were collected from the National Weather Service Station (Blue Grass Airport; Lexington, KY) located approx. $13.5 \mathrm{~km}$ from the experiment location. 
All pastures averaged $90 \pm 9(\mathrm{SEM})$ percent endophyte-infection across all pastures in 2013. Pastures were not sampled to determine percent infection in 2014 because infection rate is expected to be similar from year to year (Shelby and Dalrymple, 1993).

Disk meter heights (Table 2.) for continuously grazed pastures averaged 6.6 $\mathrm{cm}$ across the grazing seasons for 2013 and 2014, with pre-graze rotational averaging seven $\mathrm{cm}$ and post- graze rotational averaging five $\mathrm{cm}$.

Table 1. Average disk meter height (DMH) and forage mass (FM) for continuously and rotationally grazed pastures of a mixture of toxic endophyte-infected tall fescue, bluegrass, orchardgrass, and other species. Measures were averages over each year (2013 and 2014) and were controlled using the put-and-take stocking.

\begin{tabular}{lcc}
\hline \multicolumn{1}{c}{ Treatment } & DMH & FM \\
\hline 2013 & $\mathrm{~cm}$ & $\mathrm{~kg} \mathrm{DM} \mathrm{ha}^{-1}$ \\
Continuous & 6 & 3504 \\
Rotational Pre-graze & 7 & 4088 \\
Rotational Post-graze & 5 & 2920 \\
2014 & & \\
Continuous & 8 & 4064 \\
Rotational Pre-graze & 9 & 4572 \\
Rotational Post-graze & 5 & 2540 \\
\hline
\end{tabular}

\section{Pasture Response}

The transect method measures frequency of occurrence for the different species in the pasture canopies and does not reflect plant densities, but rather the percentage of each species in the fresh weight of the canopy. All pastures were primarily composed of tall fescue, bluegrass, orchardgrass, and other species of cool-season grasses (Table 
3.). There were no year effects $(P>0.10)$ for tall fescue, bluegrass, orchardgrass, or other species, and no $(P>0.10) \mathrm{yr} x$ trt or trt $\mathrm{x}$ grazing cycle interactions for grazing method or species of forage. This indicates the different dates that grazing was initiated and genders in each year were not factors in causing a year effect. Rotationally grazed pastures had greater $(P=0.01)$ percentages of tall fescue compared to continuously grazed pastures, and tall fescue increased $(P=0.07)$ in canopies of rotationally grazed pastures after each grazing cycle, from $36.8 \%$ of the total composition of forage species at the initiation of the grazing study to $45.7 \%$ at the conclusion of the third and final grazing cycle. There was no effect $(P>0.10)$ for treatment or grazing cycle for bluegrass or orchardgrass. The other species components decreased $(P=0.10)$ as the grazing season continued; from $14.6 \%$ at the start of grazing to $11.3 \%$ at the end of grazing cycle three.

In agreement with Aiken et al. (2012), tall fescue in the present experiment was visually observed to be heavily spot grazed in continuous pastures. Because the reproductive stage of the tall fescue was inhibited by chemical seed head suppression, the forage could be more palatable and desirable to the cattle, causing them to increase their consumption of the vegetative tall fescue. Aiken et al. (2012) reported an increase in CP, WSC, and IVDDM in fescue that was treated with Chaparral for seedhead suppression compared with tall fescue that was untreated.

Because of the greater nutritive value of the tall fescue in this study than it would have been had it been untreated (Aiken et al., 2012), the cattle likely preferentially grazed it compared to the other grass species available for grazing. Cattle in rotationally grazed pastures were not observed to exhibit the same degree of selective 
grazing as in continuously grazed pastures because the higher stocking densities (4321.0 $\mathrm{kg} \mathrm{BW} \mathrm{ha}^{-1}$ in rotationally grazed pasture versus $\mathrm{kg} \mathrm{BW} \mathrm{ha}^{-1}$ in continuously grazed pastures) encourages more uniform grazing. Aiken et al. (2012) reported visual observation of preferential consumption of tall fescue compared to bluegrass in continuously grazed, Chaparral-treated mixed cool season grass pastures. It was suggested that selective grazing of tall fescue likely caused the aboveground herbage mass of the fescue to be reduced while Kentucky bluegrass readily set seed and accumulated to a point it became overly mature, which the present experiment supports.

Table 2. Botanical compositions in the canopies of pastures for continuously and rotationally grazed treatments. Different letters refer to a difference $(P<0.10)$ in means between treatments across 2013 and 2014. Values are shown as a percentage of total species within each management treatment.

\begin{tabular}{|c|c|c|c|c|}
\hline & Tall Fescue & Bluegrass & Orchardgrass & Other \\
\hline Treatment & & ---- $\%$ & & --.- \\
\hline Continuous & $34.6 \mathrm{~b}$ & 45.1 & 8.4 & 13.8 \\
\hline Rotational & $46.2 \mathrm{a}$ & 39.6 & 4.3 & 12.8 \\
\hline SEM & 4.32 & 4.51 & 2.70 & 2.23 \\
\hline
\end{tabular}

There was no treatment effect $(P>0.10)$ or $y r x$ trt interaction $(P>0.10)$ for density of tall fescue crowns. The density of tall fescue crowns across all pastures decreased $(P=0.01)$ from 2013 to 2014, from 6.7 to $5.1 \%$, respectively. Although reduced tall fescue crowns occurred from 2013 to 2014, dead plants were not observed in any pasture and it also was visually observed that crowns increased in diameter, possessing a greater percentage of the quadrat in which they were measured. In future 
research, the diameter of fescue crowns should be measured along with count within a quadrat so the increase in size can be objectively quantified. Close, selective grazing of the tall fescue in continuous pastures could have encouraged tillering of the tall fescue. Studies have shown an inverse relationship between tiller mass and tiller density (Kays and Harper, 1974; Bircham and Hodgson, 1983; Matthew et al., 1996). As tiller mass decreases, or is defoliated, tiller density increases. In a study by Bircham and Hodgson (1983) evaluating the influence of herbage mass under continuously grazed sheep allowing 500, 700, 1000, and $1700 \mathrm{~kg}$ organic matter (OM) ha $\mathrm{ha}^{-1}$, and reported that tiller densities were lowest at $500 \mathrm{~kg} \mathrm{OM} \mathrm{ha}^{-1}$, greatest at the 700 treatment, and as stocking rate increased, tiller densities declined. As grazing pressure increased, this encouraged greater tillering of the ryegrass and Poa annua to a point; however, as grazing intensities increased past the $700 \mathrm{~kg} \mathrm{OM} \mathrm{ha}^{-1}$ allowance, the sward became unstable and the rate of tiller loss due to uprooting became greater.

In the current study, tall fescue crown could have increased in diameter as a result of repeated defoliation causing an increase in tillering. It also plausible that maintaining the tall fescue in a vegetative growth stage could have conserved nutrients to increase in tillering as well, resulting in increased diameter of the fescue plants. Research is needed to determine if chemical seed head suppression modify the growth and morphological characteristics of the tall fescue. 


\section{Ergovaline and Ergovalinine Concentrations in Whole Tillers}

Ergovaline plus ergovalinine combined means (Table 4$)$ were greater $(P=$ $0.04)$ for 2014 (0.99 $\left.\mathrm{mg} \mathrm{kg}^{-1} \mathrm{DM} \pm 0.08 \mathrm{SEM}\right)$ compared to $2013\left(0.63 \mathrm{mg} \mathrm{kg}^{-1} \pm 0.07\right.$ SEM), but was not affected by treatment $(P>0.10)$ and there was no yr $\mathrm{x}$ trt interaction $(P>0.10)$. The greater concentrations of ergovaline could have been increased in 2014 due to lower total precipitation across the grazing season, causing an increase in alkaloid production in endophyte-infected tall fescue (Arechavaleta, et al., 1992). 


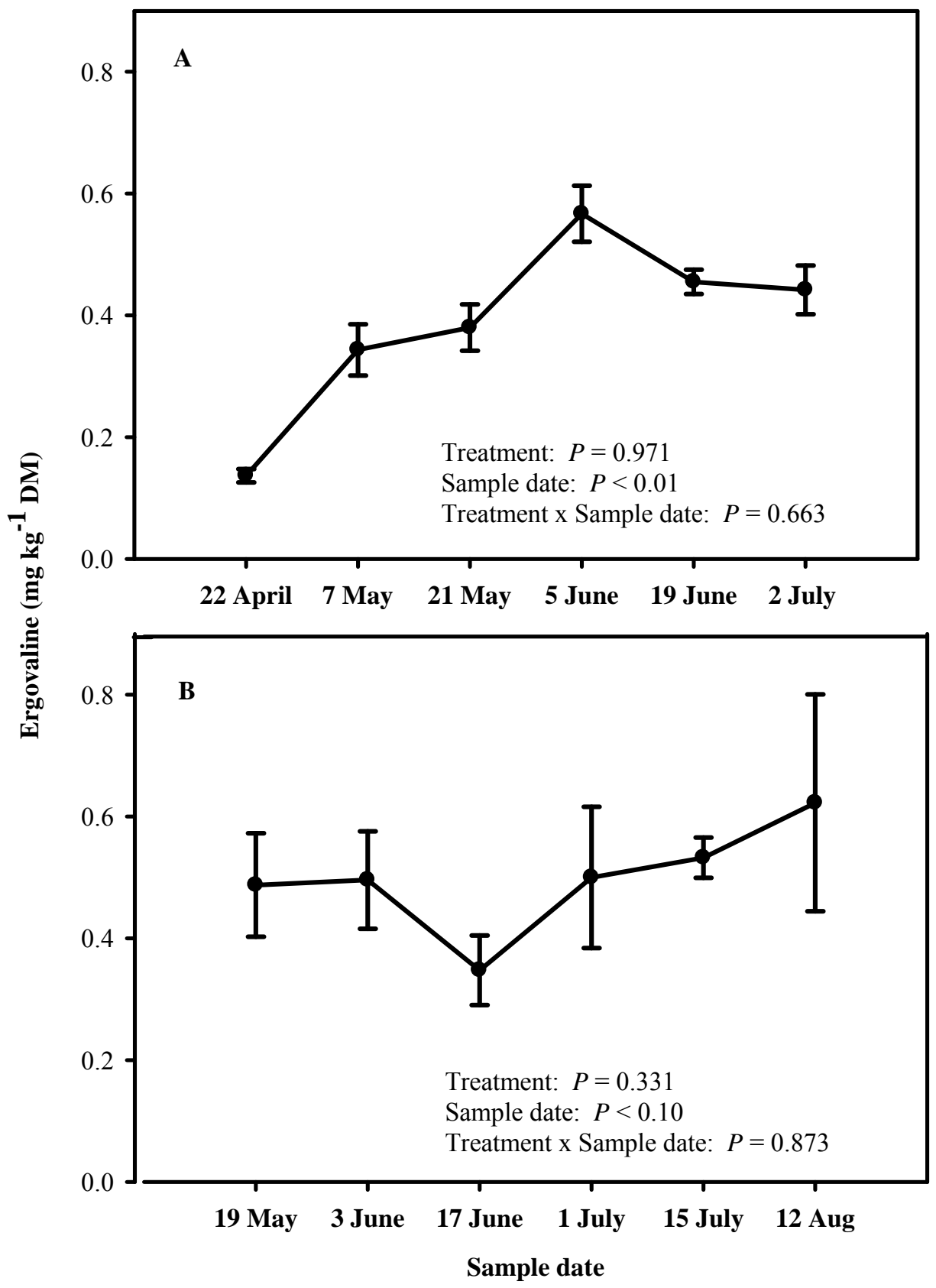

Figure 2. Ergovaline concentrations $\left(\mathrm{mg} \mathrm{kg}^{-1}\right)$ of tall fescue tiller samples across sampling dates. 


\section{Nutritive Values of Quadrat Samples}

There were no trt $\mathrm{x}$ grazing cycle interactions $(P>0.10)$ for NDF, ADF, and IVDDM. There was a yr $\mathrm{x}$ trt interaction $(P \leq 0.1)$ for NDF, ADF, and IVDDM (Table 4). In 2013, pre- graze rotational pastures had less NDF and ADF compared to postgraze rotational and continuous grazing, which did not differ $(P>0.10)$. In 2014 , there was no difference $(P>0.10)$ in NDF or ADF across grazing treatments. In vitro digestible dry matter was greater $(P=0.02)$ in pre-grazed rotational pastures compared with post-graze rotational or continuous pastures in 2013 , and was less $(P=0.02)$ in post-graze rotational in 2014 compared with pre-graze rotational and continuous, which did not differ $(P>0.10)$. As previously discussed, selective grazing that occurred in continuous pastures allowing the forage species that were selected against to accumulate growth, become reproductive, and decline in nutritive value. In rotationally grazed pastures, cattle were grazed the leafy portion of the plant and after being moved to a new paddock with higher quality plant portions available, thus leaving the stemmy, less nutritious portions in post-grazed paddocks. 
Table 3. Mean neutral detergent fiber (NDF), acid detergent fiber (ADF), and in vitro digestible dry matter (IVDDM) in quadrats $\left(0.25 \mathrm{~m}^{2}\right)$ clipped from continuously and rotationally grazed pastures. Different letters between treatments within years refer to significant difference $(P<0.10)$.

\begin{tabular}{|c|c|c|c|}
\hline Treatment & NDF & ADF & IVDDM \\
\hline 2013 & \multicolumn{3}{|c|}{ 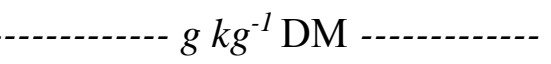 } \\
\hline Continuous & $529 \mathrm{a}$ & $294 \mathrm{a}$ & $729 b$ \\
\hline Rotational - Pre-graze & $500 \mathrm{~b}$ & $276 \mathrm{~b}$ & $773 \mathrm{a}$ \\
\hline Rotational - Post-graze & 529 a & $294 \mathrm{a}$ & $721 \mathrm{~b}$ \\
\hline SEM & 5.04 & 4.84 & 9.72 \\
\hline \multicolumn{4}{|l|}{2014} \\
\hline Continuous & 556 & 320 & $688 \mathrm{a}$ \\
\hline Rotational - Pre-graze & 555 & 321 & $668 \mathrm{a}$ \\
\hline Rotational - Post-graze & 565 & 318 & $646 \mathrm{~b}$ \\
\hline SEM & 5.91 & 5.94 & 11.91 \\
\hline
\end{tabular}

Crude protein was lower $(P=0.06)$ in post-graze rotational pastures compared to pre- graze rotational and continuous, which did not differ (Table 5). Crude protein was greater $(P=0.03)$ in $2013\left(159.9 \mathrm{~g} \mathrm{~kg}^{-1} \pm 1.5 \mathrm{SEM}\right)$ compared to $2014\left(109.1 \mathrm{~g} \mathrm{~kg}^{-1} \pm\right.$ 1.8 SEM) across all treatments. This could be due to the high amounts of precipitation and cooler growing season in 2013 compared to 2014 (Figure 1.). May is a month when cool-season grasses actively growin the transition zone of the United States. Drier conditions in May 2014 could have been a contributing factor in the lower $\mathrm{N}$ content of the forage for this year. Water-soluble carbohydrates in aboveground plant material were greater $(P=0.01)$ in continuous pastures compared to pre- and post-graze rotational pastures, which did not differ. In 2013, WSClevels in aboveground plant material were greater $(P=0.04)$ compared to levels in 2014 . Goff etal. (2012) warned that diurnal and environmental variation in WSC causes this measure to be unreliable. 
Table 4. Crude protein (CP) and water soluble carbohydrates (WSC) for quadrat $\left(0.25 \mathrm{~m}^{2}\right)$ samples from continuously and rotationally grazed pastures across years. Different letters between treatments refer to a significant difference $(P<0.10)$.

\begin{tabular}{lcr}
\hline & CP & \multicolumn{1}{c}{ WSC } \\
\hline Treatment & $----g \mathrm{~kg}^{-1} \mathrm{DM}-----$ \\
Continuous & $136 \mathrm{a}$ & $221.34 \mathrm{a}$ \\
Rotational - Pre-graze & $136 \mathrm{a}$ & $206.10 \mathrm{~b}$ \\
Rotational - Post-graze & $128 \mathrm{~b}$ & $204.74 \mathrm{~b}$ \\
\multicolumn{1}{c}{ SEM } & 2.1 & 1.50 \\
\hline
\end{tabular}

In root samples collected before the start of the grazing trial and at the end of grazing both years of the study, there was a yr $\mathrm{x}$ trt interaction $(P=0.01)$ (Figure 2$)$ and an effect on sampling period $(P=0.007)$. In 2013 , there was no difference $(P=0.60)$ in root WSC among treatments; however, in 2014, WSC levels were greater $(P=0.01)$ in rotationally grazed pastures compared with continuously grazed pastures. These results indicate that the selective grazing of tall fescue plants that occurred in this study on continuous pastures could have resulted in a depletion of root carbohydrate levels. The spots that were selected over the other specieswithin the pasture remained the same across both years of the grazing trial, and these results show that with repeated defoliation of the same tall fescue plants within the continuous pasture, root watersoluble carbohydrates declined drastically, potentially leading to a further decline in tall fescue population. Plants that were sampled prior to the start of the study had greater $(P$ $=0.007) \mathrm{WSC}$ compared with samples collected after the end of grazing, at 22.81 to $21.07 \mathrm{~g} \mathrm{~kg}^{-1} \mathrm{WSC}$, respectively. Further research is needed to determine whether prolonged continuous grazing on chemically suppressed tall fescue will permanently damage the stand of fescue within a mixed species grass pasture as a consequence of 
depleted stores of WSC within tall fescue roots. Rotational grazing could aid in improving root mass and WSC within the roots of the tall fescue, potentially improving the overall plant health and sustainability of the pasture when this practice of seedhead suppression is implemented.

Roots that were collected in 2013 had greater $(P=0.10) \mathrm{N}$ content compared with roots from 2014 with 11.8 and $10.4 \mathrm{~g} \mathrm{~kg}^{-1} \mathrm{~N}$, respectively, but this likely reflected lower soil $\mathrm{N}$ status in 2013. There was no effect on treatment $(P=0.28)$ or $\mathrm{yr} \mathrm{x} \operatorname{trt}$ interaction $(P=0.20)$ for $\mathrm{N}$ content in roots. Roots that were collected prior to the start of the grazing study had greater $\left(11.6 \mathrm{~g} \mathrm{~kg}^{-1} \mathrm{~N} ; P=0.06\right) \mathrm{N}$ content compared to roots that were sampled after the end of the grazing study $\left(10.7 \mathrm{~g} \mathrm{~kg}^{-1} \mathrm{~N}\right)$. This could be expected since cool-season grasses are most photosynthetically active in spring of the year.

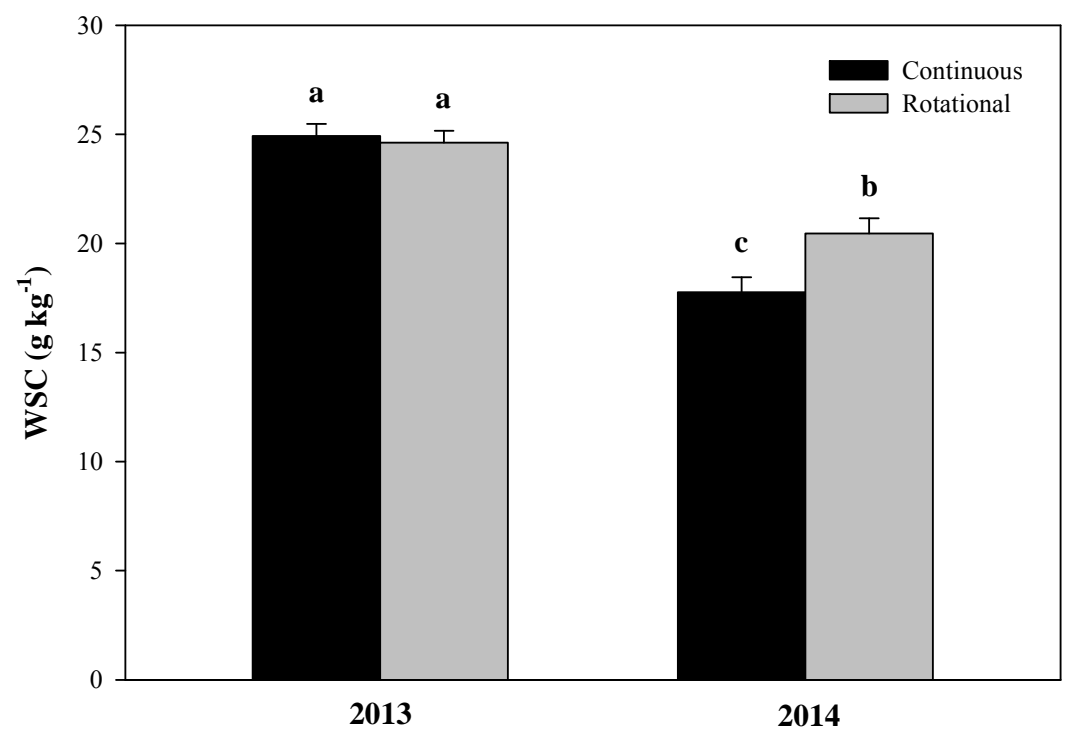

Figure 3. Water soluble carbohydrates (WSC) for tall fescue root samples from continuously and rotationally grazed pastures across years. Different letters between treatments refer to a statistical difference $(P<0.10)$. 


\section{Pasture Carrying Capacity}

Carrying capacity with rotational grazing was greater $(P=0.07)$ than with continuous grazing, with the capacities being $271 \pm 21$ (SEM) and $226 \pm 21$ (SEM) AU $\mathrm{d} \mathrm{ha}^{-1}$, respectively (Table 5.). Cattle on rotational pastures were confined to a smaller grazing area, forcing them to consume more of the available plant material, resulting in more uniform grazing and growth of the material after the animals were removed from the paddock. This combined with generation of three-wk of regrowth, encouraged increases in grazing days per AU on rotational grazing compared to continuous. There was no effect of year $(P=0.74)$ or yr $\mathrm{x}$ trt interaction $(P=0.59)$ for carrying capacity. Hull et al. (1967) and Aiken et al. (1998) reported that more animal grazing days per hectare and improved stocking rates resulted in a greater increase in gain per land area when pastures were rotationally grazed.

Greater carrying capacity on rotationally grazed pastures meant that stocking rates averaged across the grazing seasons also were greater $(P=0.07)$ on pastures that were rotationally grazed compared to continuous stocking (Figure 4). There was no effect of year $(P=0.74)$ or $\mathrm{yr} \mathrm{x}$ trt interaction $(P=0.59)$ for stocking rate. Although studies show that rotationally grazed pastures usually offer no improvement in individual animal performance (Hull et al., 1967) from either low-intensive or highintensive systems, rotational grazing encourages uniform utilization of the available forage in the pasture, which leads to these pastures carrying more animals (Aiken, 1998; Ball et al., 2007).

There was no effect of year $(P=0.77)$, treatment $(P=0.77)$, or yr $\mathrm{x}$ trt interaction $(P=0.52)$ for forage availability (Table 5.). 
Table 5. Carrying capacity (CC), stocking rate (SR), and forage availability (FA) of treatments across both years. Different letters between treatments refer to a statistical difference $(P<0.10)$.

\begin{tabular}{lccc}
\hline \multicolumn{1}{c}{ Treatment } & CC & SR & FA \\
\hline 2013 and 2014 & $\mathrm{AU} \mathrm{d} \mathrm{ha}^{-1}$ & $\mathrm{~kg} \mathrm{BW} \mathrm{ha}^{-1}$ & $\mathrm{~kg} \mathrm{DM} \mathrm{AU}^{-1} \mathrm{ha}^{-2}$ \\
Continuous & $226 \mathrm{~b}$ & $917 \mathrm{~b}$ & 1305 \\
Rotational & $271 \mathrm{a}$ & $1097 \mathrm{a}$ & 1271 \\
SEM & 21.6 & 87.7 & 94.8 \\
\hline
\end{tabular}

\section{Animal Responses}

There was no yr $\mathrm{x}$ treatment interaction $(P=0.903)$. Although pasture weight gains are typically lower for heifers than steers (Tanner et al., 1970) inferences cannot be made regarding gender in the present experiment because of confounding with year environments. Cattle in the rotationally grazed treatment had greater $(P=0.05)$ ADG than cattle on continuously grazed pastures (Figure 4.). Botanical composition data indicated there was selective grazing of the tall fescue, allowing for the accumulation of Kentucky bluegrass and orchardgrass. As the bluegrass and orchardgrass accumulated and became more mature, reduced forage quality likely occurred. After cattle had selectively grazed the treated fescue and orchardgrass in continuously grazed pastures, they were forced to graze the mature, lower quality bluegrass, which likely accounts for reduced animal gains. Aiken et al. (2012) reported a 39\% greater ADG in cattle grazing chemically suppressed tall fescue compared with cattle grazing unsuppressed tall fescue in mixed species pastures. Selective grazing of tall fescue treated with Chaparral to suppress seedhead emergence also occurred in that study, resulting in a lower percentage of above ground tall fescue at the end of the grazing study as a result of the 
selective grazing.

Steers exhibited greater $(P=0.03)$ gains per hectare (Figure 5.) in 2013 compared to heifers in 2014 . This was likely due, in part, to the increased nutritive values of the forage in the first year of the study compared to the nutritive values in 2014. There was no yr $\mathrm{x}$ treatment interaction $(P=0.52)$ for gain per hectare; however, cattle grazing rotationally had greater $(P=0.08)$ gains per hectare compared to cattle on continuously grazed pastures. Most studies have shown an increase in animal performance on continuous grazing compared to rotational grazing (Hull et al., 1967; Kee et al., 1991; Aiken, 1998; Ball et al., 2007), as a result of greater selectivity with continuous grazing. However, Lehmkuhler et al. (1999) reported a tendency toward greater ADG in cattle on rotationally grazed silvopastures compared with continuous grazing as an effect of a high degree of selective grazing resulting in a reduced forage quality in continuous pastures. A grazing study by Walker et al. (1989) reported that the quality of diet in rotationally grazed pastures did not differ from diet quality of continuously grazed pastures, although carrying capacity was increased in rotationally grazed pastures. A study by Hull et al. (1967) found that with continuous grazing, BW gain ha ${ }^{-1}$ was greater and energy gain per hectare was greater than for animals on rotationally grazed pastures. 


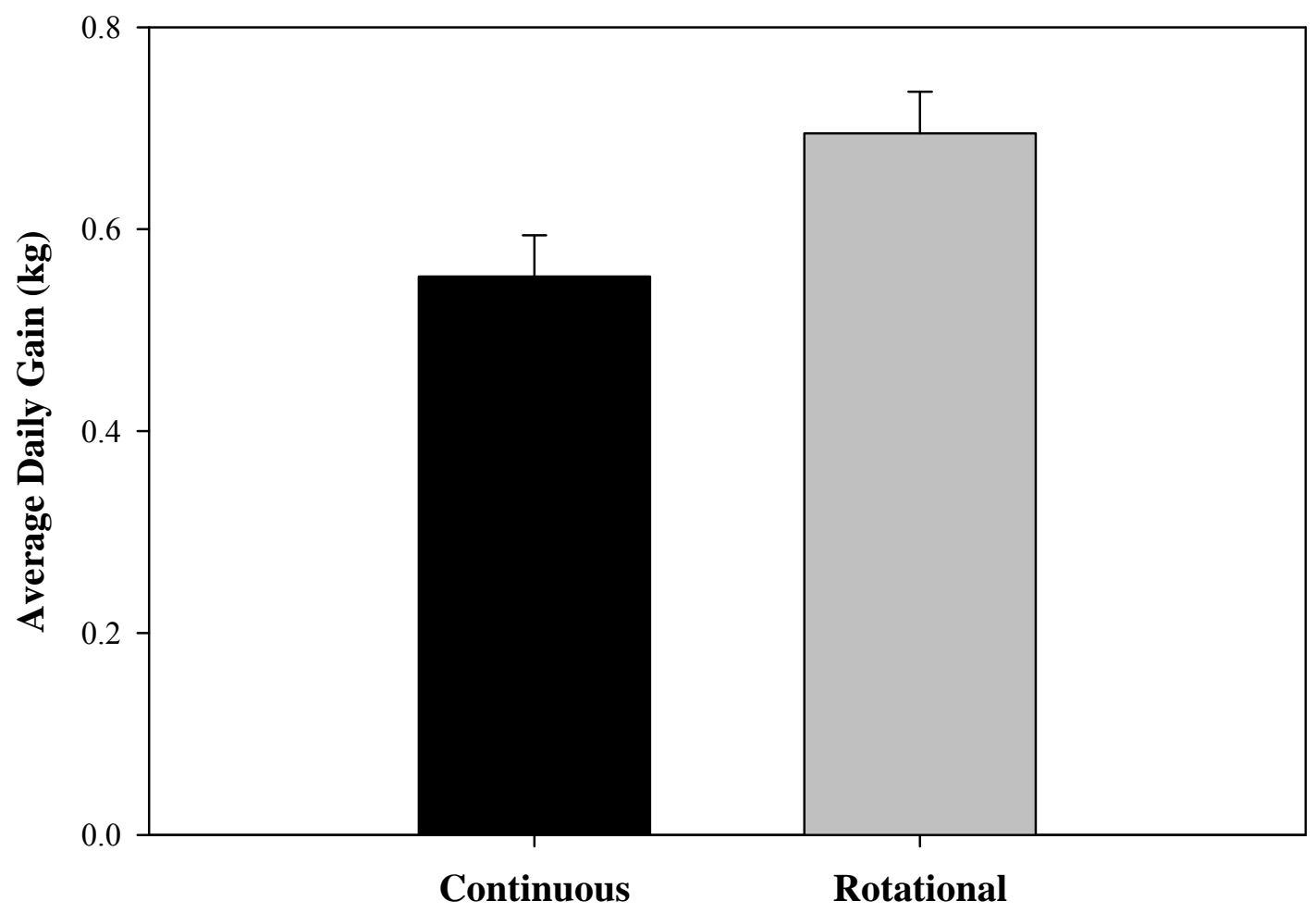

Figure 4. Average Daily Gain ( $\mathrm{kg}$ ) of continuously and rotationally grazed pastures across both years. 


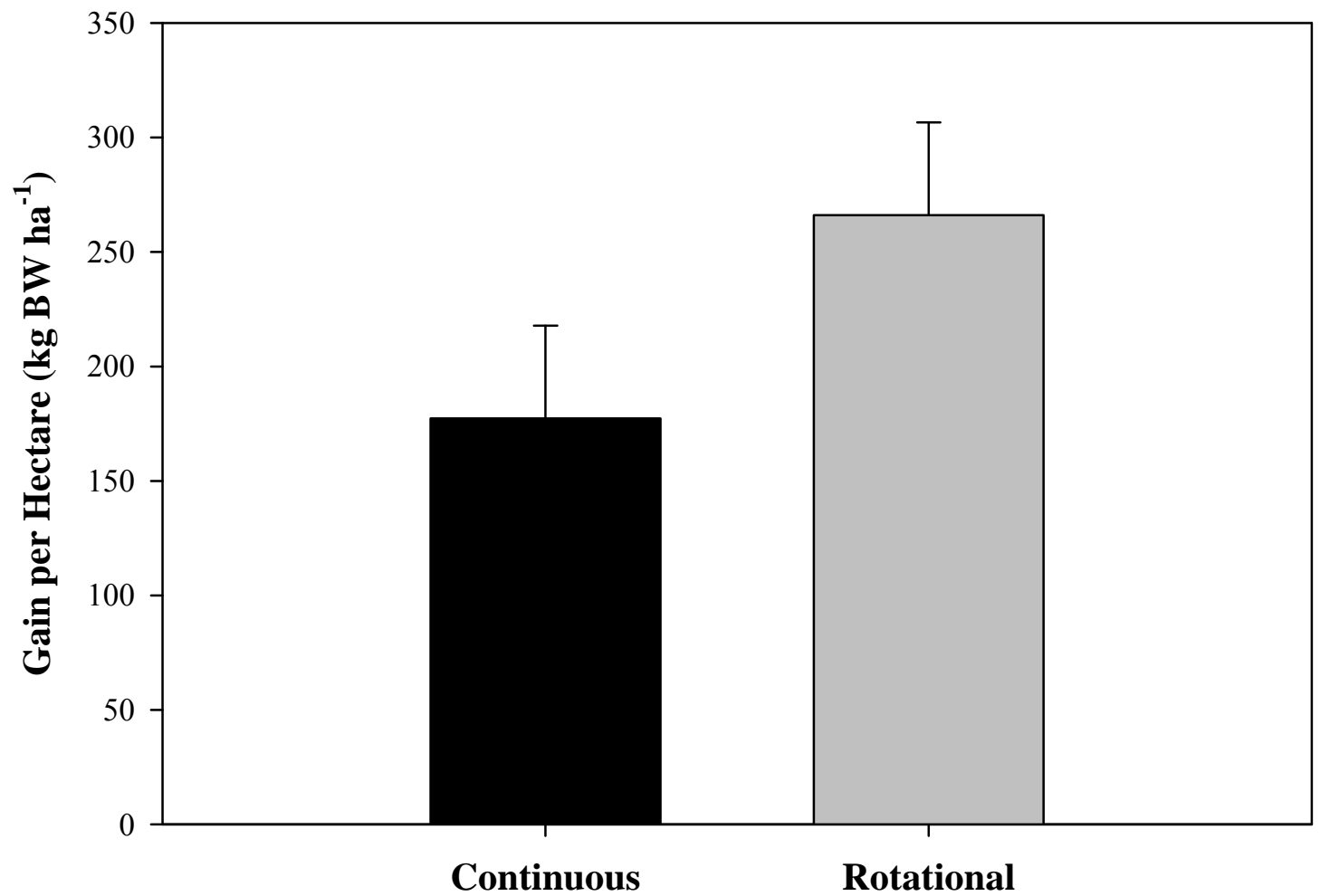

Figure 5. Gain per hectare $\left(\mathrm{kg} \mathrm{BW} \mathrm{ha}^{-1}\right)$ of continuously and rotationally grazed pastures across both years.

Copyright (C Jessica A. Williamson 2015 


\section{CHAPTER V: Conclusions}

Applying Chaparral to suppress seedhead emergence in tall fescue to mitigate fescue toxicosis, in managed grazing systems could be the key to prolonged sustainability of pastures. This grazing experiment indicated that rotational grazing of chemically seed head suppressed pastures of toxic tall fescue and bluegrass can lead to increased carrying capacities over those that are continuously grazed, while improving the uniformity in grazing of other cool-season grasses to improve overall forage quality. As a result, calf ADG were greater on rotationally grazed pastures compared with continuously grazed. Greater ADG and carrying capacities led to substantial increase in gain per hectare. Rotational grazing forced animals to graze all available forage species, as animals were concentrated in a small area within a pasture, reducing the amount of selective grazing within a pasture and creating a uniform utilization of all forage species available. With continuous grazing, the opportunity to selectively graze the vegetative tall fescue led to overgrazing of the fescue and the accumulation and maturation of other forage species. This caused lower quality forages to be grazed out of necessity in the latter parts of the season when the higher quality, more palatable tall fescue was over-grazed. An increase in forage nutritive values, including NDF, ADF, and IVDDM, and greater root WSC levels can be achieved with rotational grazing when using chemical to suppress seedhead emergence in an effort to mitigate fescue toxicosis. Based on this study, improved overall pasture and per animal and hectare output can be achieved by implementing a rotational grazing management strategy when chemically suppressing seedhead emergence in tall fescue.

Copyright (C) Jessica A. Williamson 2015 


\section{CHAPTER VI: Implications}

Overall sustainability of a grazing system that utilizes chemical seedhead suppression to mitigate fescue toxicosis should implement a managed rotational grazing system to improve the overall sustainability of the pasture and the system as a whole. By rotationally grazing, pasture performance can be optimized by improving forage quality and carrying capacity as well asanimal performance and per hectare production. 


\section{LITERATURE CITED}

Aiken, G.E., D.I. Bransby, and C.A. McCall. 1993. Growth of yearling horses compared to steers on high- and low-endophyte infected tall fescue. J. Equine Vet. Sci. 13:26-28.

Aiken, G.E. 1998. Steer performance and nutritive values for continuously and rotationally stocked bermudagrass sod-seeded with wheat and ryegrass. J. Prod. Agric. 11:185-190.

Aiken, G.E., M.L. Looper, S.F. Tabler, D.K. Brauer, J.R. Strickland, and F.N. Schrick. 2006. Influence of stocking rate and steroidal implants on growth rate of steers grazing toxic tall fescue and subsequent physiological responses. J. Anim. Sci. 84:1626-1632.

Aiken, G.E., B.H. Kirch, J.R. Strickland, L.P. Bush, M.L. Looper, and F.N. Schrick. 2007. Hemodynamic responses of the caudal artery to toxic tall fescue in beef heifers. J. Anim. Sci. 85:2337-2345.

Aiken G.E., J.R. Strickland, M.L. Looper, L.P. Bush, and F.N. Schrick. 2009. Hemodynamics are altered in the caudal artery of beef heifers fed different ergot alkaloid concentrations. J. Anim. Sci. 78:2142-2150.

Aiken, G.E., B.M. Goff, W.W. Witt, I.A. Kagan, B.B. Sleugh, P.L. Burch, and F.N. Schrick. 2012. Steer and plant responses to chemical suppression of seedhead emergence in toxic endophyte-infected tall fescue. Crop Sci. 52:960-969.

Aiken, G.E. and J.R. Strickland. 2013. Forages and pasture symposium: Managing the tall fescue-fungal endophyte symbiosis for optimum forage-animal production. J. Anim. Sci. 91:2369-2378.

Aiken, G.E. and M.D. Flythe. 2014. Vasconstructive responses by the carotid and auricular arteries in goats to ergot alkaloid exposure. Front. Chem. doi: 10.3389/fchem.2014.00101.

Aldrich, C.G., J.A. Paterson, J.L. Tate, and M.S. Kerley. 1993. The effects of endophyte-infected tall fescue consumption on diet utilization and thermal regulation in cattle. J. Anim. Sci. 71:164-170.

Allain, D., L. Martinet, and J. Rougeot. 1981. Effects of melatonin implants on changes in the coat, plasma prolactin and testis cycle in the mink (Mustela visonl. In: R. Ortavant, J. Pelletier, and J. P. Ftauvault (Ed.) Photoperiodism and Reproduction in Vertebrates. p 203. INRA Services Publications, Versailles, France.

ANKOM Technology. 2005. Method 3: In vitro true digestibility using the ANKOM Daisy II incubator. ANKOM Technology, Macedon, NY. 
Arechavaleta, M., C.W. Bacon, R.D. Plattner, C.S. Hoveland, and D.E. Radcliffe. 1992. Accumulation of ergopeptide alkaloids in symbiotic tall fescue grown under deficits of soil water and nitrogen fertilizer. Appl. Environ. Microbiol. 58:857-861.

Bacon, C.W., J.K. Porter, J.D. Robbins, and E.S. Luttrell. 1977. Epichloe typhina from toxic tall fescue grasses. Appl. Environ. Microbiol. 35:576-587.

Bacon, C.W., P.C. Lyons, J.K. Porter, and J.D. Robbins. 1986. Ergot toxicity from endophyte- infected grasses: A review. Agron. J. 78:106-116.

Ball, D.M., C.S. Hoveland, and G.D. Lacefield. 2007. Southern Forages. International Plant Nutrition Institute. Norcross, Georgia.

Berde, B. 1980. Ergot compounds: A synopsis. p. 4-23 In: Ergot compounds and brain function: Neuroendocrine and neuropsychiatric aspects. M. Goldstein, A. Lieberman, D.B. Calne, and M.O. Thorner, ed. Raven Press, New York, NY.

Blaser, R.E., R.C. Hammes Jr., H.T. Bryant, C.M. Kincaid, W.H. Skyrdia, T.H. Taylor, and W.L. Griffeth. 1956. The value of forage species and mixtures for fattening steers. Agron. J. 48:508-513.

Boling, J.A. 1985. Endophytic fungus and tall fescue utilization by ruminants. Prof. Anim. Sci. 1:19.

Bircham, J.S., and J. Hodgson. 1983. The influence of sward condition on rate of herbage growth and senescence in mixed swards under continuous stocking management. Grass and Forage Science 38:323-331.

Boman, R.S., H.T. Bryant, R.C. Hammes, Jr., and R.E. Blaser. 1973. The value of two tall fescue varieties for lactating milk cows. p. 31-34. In G.B. Garner, H.L. Tookey, and D.R. Jacobson (ed.) Proc. Fescue Tox. Conf., Lexington, KY. 31 May-1 June. Univ. Missouri, Columbia, MO.

Bond, J., J.B. Powell, and B.T. Weinland. 1984. Behavior of steers grazing several varieties of tall fescue during summer conditions. Agron. J. 76:707-709.

Borrill, M. 1976. Temperate Grasses. P. 137-142. In N.W. Simmonds (ed.). Evolution of Crop Plants. Longman, London and New York.

Bouton, J.H., R.N. Gates, D.P. Belesky, and M. Owsley. 1993. Yield and persistence of tall fescue in the southeastern coastal plain after removal of its endophyte. Agron. J. 85:52- 55.

Bouton, J.H., G.C.M. Latch, N.S. Hill, C.S. Hoveland, M.A. McCann, R.H. Watson, J.A. Parish, L.L. Hawkins, and F.N. Thompson. 2002. Reinfection of tall fescue cultivars with nonergot alkaloid-producing endophytes. Agron. J. 94:567-574. 
Bransby, D.I., S.P. Schmidt, W. Griffey, and J.T. Eason. 1988. Heavy grazing is best for infected fescue. Alabama Agric. Exp. Sta. Highlights Agric. Res. 35(4):12.

Bransby, D.I. 1991. Biological implications of rotational and continuous grazing: A case for continuous grazing. p. 10-13 In Proc. Forage and Grassland Conf., Columbia, MO. 1-4 Apr. 1991. American Forage and Grassland Council, Georgetown, TX.

Brown, M.A., L.M. Tharel, A.H. Brown, Jr., J.R. Miesner, and W.G. Jackson. 1992. Reproductive performance of Angus and Brahman cows grazing common bermudagrass or endophyte-infected tall fescue. Prof. Anim. Sci. 8:58-65.

Browning, R., Jr., S.J. Gissendanner, and T. Wakefield. 2000. Ergotamine alters plasma concentrations of glucagon, insulin, cortisol, and triiodothyronine in cows. J. Anim. Sci. 78:690-698.

Browning R., Jr., 2004. Effects of endophyte-infected tall fescue on indicators of thermal status and growth in Hereford and Senepol. J. Anim. Sci. 82:634-643.

Burke, J.M., C. Bishop, and F. Stormshak. 2006. Reproductive characteristics of endophyte- infected or novel tall fescue fed to ewes. Livest. Sci. 104:103-111.

Bush, L., and R.C. Buckner. 1973. Tall fescue toxicity. P. 99-112. In A.G. Matches (ed.) Anti- quality components of forages. Spec. Pub. 4 CSSA. Madison, WI.

Bush, L., J. Boling, and S. Yates. 1979. Animal disorders. In R.C. Bucker and L.P. Bush (ed.) Tall Fescue. Agronomy 20:247-292.

Bush, L., and F.F. Fannin. 2009. Alkaloids. p. 229-249 In Tall Fescue for the Twentyfirst Century. H.A. Fribourg, D.B. Hannaway, and C.P. West, ed. ASA, CSSA, and SSSA. Madison, WI.

Carter, J.M., G.E. Aiken, C.T. Dougherty, and F.N. Schrick. 2010. Steer responses to feeding soybean hulls and steroid hormone implantation on toxic tall fescue pasture. J. Anim. Sci. 88:3759-3766.

Christensen, M.J., O. Ball, R.J. Bennett, C.L. Schardl. 1997. Fungal and host genotype effects on compatibility and vascular colonization by Epichloe festucae. Mycological Research 59:1540-1548.

Christensen, M.J., R.J. Bennett, and J. Schmid. 2001. Vascular bundle colonization by Neotyphodium endophytes in natural and novel endophytes in natural and novel associations with grasses. Mycol. Res. 105:1239-1245.

Christensen, M.J., R.J. Bennett, J. Schmid. 2002. Growth of Epichloe/Neotyphodium and p- endophytes in leaves of grass hosts. Mycological Research 106:93-106.

Christensen, M.J., and C.R. Voisey. 2007. The biology of the endophyte/grass partnership. p. 123-133. New Zealand Association: Endophyte Symposium. 
Coffey, K.P., L.W. Lomas, and J.L. Moyer. 1990. Grazing and subsequent feedlot performance by steers that grazed different types of fescue pasture. J. Prod. Agric. 3:415.

Cole, N.A., J.A. Stuedemann, C.W. Purdy, and D.P. Hutcheson. 1987. Influence of endophyte in tall fescue pastures on the feedlot performance of feeder steers. J. Anim. Sci. 65(Suppl):331.

Dalrymple, R.L. 1996. Forage management practical applications. p. 5-9. In Proc. Arkansas Forage and Grassland Conf., Ferndale, AR. 24 Oct. Arkansas Coop. Ext. Serv., Little Rock.

Dow AgroSciences. 2011. Chaparral specialty herbicide: Specimen label [Online]. Available at http://www.cdms.net/CDat//d8QG009.pdf (verified 5 May 2011). Dow AgroSciences LLC, Indianapolis, IN.

Duckett, S., J. Andrae, M. A. McCann, and D. Gill. 2001. Performance and carcass quality of cattle finished after grazing non-toxic endophyte-infected (MaxQ), toxic endophyte- infected, or endophyte- free tall fescue. Page 15 in Proc. Tall Fescue Toxicosis Workshop, Chapel Hill, TN.

Eckert, H., J.R. Kiechel, J. Rosenthaler, R. Schmidt, and E. Schreier. 1978. Chapter 11: Biopharmaceutical Aspects. p. 1-28. In Ergot Alkaloids and Related Compounds. B. Berde and H.O Schild, ed. Springer-Verlag, Berlin, Heildelberg, New York.

Fergus, E.N. 1952. Kentucky 31 Fescue - Culture and Use. Kentucky Agric. Ext. Circ. 497. Fergus, E.N. and R.C. Buckner. 1972. Registration of Kentucky 31 Tall Fescue. (Reg. NO. 7) Crop Sci. 12:714.

Forcherio, J.C., M.S. Kerley, and J.A. Paterson. 1992. Performance of steers grazing tall fescue during the spring followed by warm-season grasses during the summer. J. Anim. Sci. 70 (Suppl. 1):182.

Forcherio, J.C., J.A. Paterson, and M.S. Kerley. 1993. Effects of supplemental energy or protein on rumen parameters and performance of first and second partum beef cows grazing tall fescue. J. Anim. Sci. 71(Suppl. 1):197.

Garner, G.B., and C.N. Cornell. 1987. University of Missouri report on fescue research activities (preliminary report). Proc. Tall Fescue Toxicosis Workshop, Nov. 1718, Memphis, TN.

Gay, N., J.A. Boling, R. Dew, and D.E. Miksch. 1988. Effects of endophyte-infected tall fescue on beef cow-calf performance. Appl. Agric. Res. 3:182-186.

Glenn, A.E., C.W. Bacon, R. Price, and R.T. Hanlin. 1996. Molecular Phylogeny of Acremonium and its taxonomic implications. Mycologia 88:369-383. 
Goetsch, A.L., A.L. Jones, K.W. Beers, S.R. Stokes, and E.L. Piper. 1987. Effect of offering different amounts and types supplemental feeds to growing dairy steers fed endophyte- infected fescue hay ad libitum on intake, digestion, passage rate, and serum prolactin concentration. J. Anim. Sci. 64:1769-1778.

Goff, B.M., G.E. Aiken, W.W. Witt, B.B. Sleugh, and P.L. Burch. 2012. Steer consumption and ergovaline recovery from in vitro digested residues of tall fescue seedheads. Crop Sci. 52:1437-1440.

Goff, B.M. 2012. Steer and tall fescue pasture responses to grazing intensity and chemical seedhead suppression. PhD Dissertation, University of Kentucky, Lexington, $\mathrm{KY}$.

Hannah, S.M., M.T. Rhodes, J.A. Paterson, M.S. Kerley, J.E. Williams, and K.E. Turner. 1989. Influence of energy supplementation on forage intake, digestibility, and grazing time by cattle grazing tall fescue. Nutr. Rep. Int. 40:1153.

Hannah, S.M., J.A. Paterson, J.E. Williams, M.S. Kerley, and J.L. Miner. 1990. Effects of increasing dietary levels of endophyte-infected tall fescue seed on diet digestibility and ruminal kinetics in sheep. J. Anim. Sci. 68:1693.

Heldmaier, G. and G.R. Lynch. 1986. Pineal involvement in thermoregulation and acclimatization. Pineal Res. Rev. 4:97-139.

Hemken, R.W., J.A. Jackson, Jr., and J.A. Boling. 1984. Toxic factors in tall fescue. J. Anim. Sci. 58:1011-1016.

Hill, N.S., F.N. Thompson, J.A. Stuedemann, G.W. Rottinghaus, H.J. Ju, D.L. Dawe, and E.E. Hiatt. 2001. Ergot alkaloids transport across ruminal gastric tissues. J. Anim. Sci. 79:542- 549.

Hodgson, J. 1990a. Grazing management: Science into practice. Ch 9: Sward conditions, herbage intake, and animal performance. p. 81-87. Longman Scientific and Technical. New York.

Hodgson, J. 1990b. Grazing management: Science into practice. Ch 10: Output from grazing systems. p. 88-98. Longman Scientific and Technical. New York.

Hoveland, C.S., S.P. Schmidt, C.C. King, Jr., J.W. Odom, E.M. Clark, J.A. McGuire, L.A. Smith, H.W. Grimes, and J.L. Holliman. 1983. Steer performance and association of Acremonium coenophialum fungal endophyte on tall fescue pasture. Agron. J. 75:821- 824.

Hoveland, C.S. 1993. Importance and economic significance of the Acremonium endophytes to performance of animals and grass plant. Agric. Ecosyst. Environ. 44:3-12.

Hoveland, C.S., J.H. Bouton, and R.G. Durham. 1999. Fungal endophyte effects on 
production of legumes in association with tall fescue. Agron. J. 91:897-902.

Hull, J.L., J.H. Meyer, and C.A. Raguse. 1967. Rotation and continuous grazing on irrigated pasture using beef steers. J. Anim. Sci. 26:1160-1164.

Hurley, W.L., E.M. Convey, K. Leung, L.A. Edgerton, and E.R. Hemken. 1980. Bovine prolactin, TSH, T4, and T3 concentrations as affected by tall fescue summer toxicosis and temperature. J. Anim. Sci. 51:374-379.

Jacobson, D.R., S.B. Carr, R.H. Hatton, R.C. Buckner, A.P. Graden, D.R. Dowden, and W.M. Miller. 1970. Growth, physiological responses, and evidence of toxicity in yearling dairy cattle grazing different grasses. J. Dairy Sci. 53:575-587.

Jones, K.L., S.S. King, K.E. Griswold, D. Cazac, and D.L. Cross. 2003. Domperidone can ameliorate deleterious reproductive effects and reduced weight gain associated with fescue toxicosis in heifers. J. Anim. Sci. 81:2568-2574.

Jones, K.L., C.R. McCleary, S.S. King, G.A. Apgar, and K.E. Griswold. 2004. Case study: Consumption of toxic fescue impairs bull reproductive parameters. Prof. Anim. Sci. 20:437-442.

Kays, S. and J.L. Harper. 1974. The regulation of plant and tiller density in a grass sward. J. of Ecology 62(1):97-105.

Kee, D.D., D.I. Bransby, D.E. Gamble, and W.E. Ivey. 1991. Continuous versus rapid rotational grazing of 'Tifton- 44 ' bermudagrass steers at varying stocking rates. p. 198-201. In Proc. Forage and Grassland Conf., Columbia, MO. 1-4 Apr. 1991. American Forage and Grassland Council, Georgetown, TX.

Keltner, D. G., J. B. McLaren, H. A. Fribourg, A. B. Chestnut, W. T. McDonald, and D. O. Onks. 1988. Performance of crossbred cows and calves grazing tall fescue with varying levels of endophyte infestation. J. Anim. Sci 86, no. Suppl 1:55.

Klotz, J.L., L.P. Bush, D.L. Smith, W.D. Shafer, L.L. Smith, B.C. Arrington, and J.R. Strickland. 2007. Ergovaline-induced vasoconstriction in an isolated bovine lateral saphenous vein bioassay. J. Anim. Sci. 85:2330-2336.

Klotz, J.L., B.H. Kirck, G.E. Aiken, L.P. Bush, and J.R. Strickland. 2008. Effects of selected combinations of tall fescue alkaloids on vasoconstrictive capacity of fescue naïve bovine lateral saphenous veins. J. Anim. Sci. 86:1021-1028.

Lamberts, S.W.J., and R.M. McLeod. 1990. Regulation of prolactin secretion at the level of the lactotroph. Physiol. Rev. 70:279-318.

Lamson-Schribner, F. 1896. Useful and ornamental grasses. USDA Div. of Agrostology, Bull. 3.

Latch, G.C., W.F. Hunt, D.R. Musgrave. 1985. Endophytic fungi affect growth of the 
perennial ryegrass. New Zealand Journal of Agricultural Research 28:165-168.

Latch, G.C., M.J. Christensen, B.A. Tapper, H.S. Easton, D.E. Hume, and L.R. Fletcher. 2000. Tall fescue endophytes. Patent No. 6111170. U.S. Patent Off., Washington, D.C.

Lehmkuhler, J.W., M.S. Kerley, H.E. Garrett, B.E. Cutter, and R.L. McGraw. 1999. Comparison of continuous and rotational silvopastoral systems for established walnut plantations in southwest Missouri, USA. Agroforestry Systems 44:267279.

Leuchtmann, A., C.W. Bacon, C.L. Schardl, J.F. White, Jr., and M. Tadych. 2014. Nomenclature realignment of Neotyphoidium species with genus Epichloe. Mycologia 106(2):202-215.

Looper, M.L., R.W. Rorie, C.N. Person, T.D. Lester, D.M. Hallford, G.E. Aiken, C.A. Roberts, G.E. Rottinghaus, and C.F. Rosenkrans. 2009. Influence of toxic endophyte-infected fescue on sperm characteristics and endocrine factors of yearling Brahman-influenced bulls. J. Anim. Sci. 87:1184-1191.

Lusby, K.S., W.E. McMurphy, C.A. Strasia, and S.H. Muntz. 1990. Effects of fescue endophyte and interseeded clovers on subsequent finishing performance of steers. J. Prod. Agric.

$3: 103$.

Lyons, P.C., R. D. Plattner, and C. W. Bacon. 1986. Occurrence of peptide and clavine ergot alkaloids in tall fescue grasses. Science 232:487-489.

Mahmood, T., R.S. Ott, G.L. Foley, G.M. Zinn, D.J. Schaeffer, and D.J. Kesler. 1994. Growth and ovarian function of weanling and yearling beef heifers grazing endophyte-infected tall fescue pastures. Theriogenology 42:11491158 .

Matthew, C., A. Hernandez-Garay, and J. Hodgson. 1996. Making sense of the link between tiller density and pasture production. Proceedings from the New Zealand Grassland Assoc. 57:83-87.

McClanahan, L.K., G.E. Aiken, and C.T. Dougherty. 2008. Case study: Influence of rough hair coats and steroid implants on the performance and physiology of steers grazing endophyte-infected tall fescue in the summer. Prof. Anim. Sci. $24: 269-276$.

McMurphy, W.E., K.S. Lusby, S.C. Smith, S.H. Muntz, and C.A. Strasia. 1990. Steer performance on tall fescue pasture. J. Prod. Agric. 3:100-102.

Monroe, J. L., D. L. Cross, L. W. Hudson, D. M. Hendricks, S. W. Kennedy, and W. C. Bridges, Jr. 1988. Effects of selenium and endophyte-contaminated fescue on the performance and reproduction in mares. Equine Vet. Sci. 8:148. 
Morgan-Jones, G. and W. Gams. 1982. Notes on Hyphomycetes. XLI. An endophyte of Festuca arundinacea and the anamorph of Epichloe typhina, a new taxa in one of two sections of Acremonium. Mycotaxon 15:311-318.

Mott, G.O and H.J. Lucas. 1953. The design, conduct, and interpretation of grazing trials on cultivated and improved pastures. Proc. $6^{\text {th }}$ Int. Grasslands Congress, State College, PA. 2:1380-1385.

Mott, G.O., C.J. Kaiser, R.C. Peterson, Jr., and C.L. Rhykerd. 1971. Supplemental feeding of steers on Festuca arundinacea Schrebpasture fertilized at three levels of nitrogen. Agron. J. 63:751-754.

Neill, J.C. 1941. The endophyte of Lolium and Festuca. N.Z. J. Sci. Technol. Sect. A 23:185- 193.

Nihsen, M.E., E.L. Piper, C.P. West, R.J. Crawford, Jr., T.M. Denard, Z.B. Johnson, C.A. Roberts,D.A. Spiers, and C.F. Rosenkrans. 2004. Growth rate and physiology of steers grazing tall fescue inoculated with novel endophytes. J. Anim. Sci. 82:878-883.

Oliver, J.W. 2005. Pathophysiologic response to endophyte toxins. In: C.A. Roberts, C.P. West, and D.E. Spiers, editors, Neotyphodium in cool-season grasses. Blackwell, Ames, IA. p. 291-301.

Ortega-Santos, J.A., L.E. Sollenberger, K.H. Quesenberry, C.S. Jones, Jr., and J.A. Cornell. 1992. Productivity and persistence of rhizome peanut pastures under different grazing managements. Agron. J. 84:799-804.

Paterson, J., C. Forcherio, B. Larson, M. Samford, and M. Kerley. 1995. The effects of fescue toxicosis on beef cattle productivity. J. Anim. Sci. 73:889-898.

Peters, C.W., K.N. Grigsby, C.G. Aldrich, J.A. Paterson, R.J. Lipsey, M.S. Kerley, and G.B. Gerner. 1992. Performance, forage utilization, and ergovaline consumption by beef cows grazing endophyte fungus-infected tall fescue, endophyte fungus-free tall fescue, or orchardgrass pastures. J. Anim. Sci. 70:1550-1561.

Porter, J.K., J.A. Stuedemann, F.N. Thompson, Jr., and L.B. Lipham. 1990. Neuroendocrine measurements in steers grazed on endophyte-infected fescue. J. Anim. Sci. 68:3285- 3292.

Porter, J.K., and F.N. Thompson. 1992. Effects of fescue toxicosis on reproduction in livestock. J. Anim. Sci. 70:1594-1603.

Porter, J.K. 1995. Analysis of endophyte toxins: Fescue and other grasses toxic to livestock. J. Anim. Sci. 73:871-880.

Pratt, A.D. and J.L. Haynes. 1950. Herd performance on Kentucky-31 fescue. Ohio Farm Home Res. 35:10-11. 
Realini, C.E., S.K. Duckett, N.S. Hill, C.S. Hoveland, B.G. Lyon, J.R. Sackmann, and M.H. Gillis. 2005. Effect of endophyte type on carcass traits, meat quality, and fatty acid composition of beef cattle grazing tall fescue. J. Anim. Sci. 83:430439 .

Richards, C.J., R.B. Pugh, and J.C. Waller. 2006. Influence of soybean hull supplementation on rumen fermentation and digestibility in steers consuming freshly clipped, endophyte- infected tall fescue. J. Anim. Sci. 84:678-685.

Rhodes, M.T., C.G. Aldrich, J.A. Paterson, and M.S. Kerley. 1989. The effect of endophyte- infected tall fescue and a dopamine antagonist on relative blood flow in sheep. J. Anim. Sci. 67(Suppl. 1):286.

Rhodes, M.T., J.A. Paterson, M.S. Kerley, H.E. Garner, and M.H. Laughlin. 1991. Reduced blood flow to peripheral and core body tissues in sheep and cattle induced by endophyte- infected tall fescue. J. Anim. Sci. 69:2033-2043.

Robbins, J.D. 1983. The tall fescue toxicosis problem. p. 1-4 In Proc. Tall Fescue Toxicosis Workshop. Atlanta, GA. 17-18 Mar. University of Georgia Extension, Athens, GA.

Roberts, C., and J. Andrae. 2004. Tall fescue toxicosis and management. Crop Manage. doi:10.1094/CM-2004-0427-01-MG.

Rolston, M.P., and W.C. Young III. 2009. Seed production. p. 409-426. In H.A. Fribourg, D.B. Hannaway, and C.P. West (ed.) Tall Fescue for the twenty-first century. Agron. Monogr. 53. ASA, CSSA, and SSSA, Madison, WI.

Rothlin, E. 1933. Uber enterale Resoption von Mutterkornalkaloiden und deren spezifische Wirkungweise auf das Kreislaufsystem. Naunyn Schmiedebergs Arch. Exp. Pathol. Pharmakol. 171:555-591. As referenced by Aiken and Strickland, 2013.

Rottinghaus, G.E., G.B. Garner, C.N. Cornell, and J.L. Ellis. 1991. HPLC method for quantitating ergovaline in endophyte-infected tall fescue: Season variation of ergovaline levels of stem with leaf sheaths, leaf blades, and seed heads. J. Agric. Food Chem. 39:112-115.

SAS Institute. 2009. SAS/STAT user's guide. Version 9.3. SAS Institute, Cary, NC.

Schillo, K.K., L.S. Leshin, J.A. Boling, and N. Gay. 1988. Effects of endophyteinfected fescue on concentrations of prolactin in blood sera and the anterior pituitary and concentrations of dopamine metabolites in brains of steers. J. Anim. Sci. 66:713-718.

Schmidt, S.P., C.S. Hoveland, E.M. Clark, N.D. Davis, L.A. Smith, H.W. Grimes, and J.H. Holliman. 1982. Association of an endophytic fungus with fescue toxicity in steers fed Kentucky-31 tall fescue seed or hay. J. Anim. Sci. 55:1259-1363. 
Schmidt, S.P., D.A. Danielson, J.L. Holliman, H.W. Grimes, and W.B. Webster. 1986. Fescue fungus suppresses growth and reproduction in replacement beef heifers. Highlights Agric. Res. 33(4):15.

Schuenemann, G.M., J.L. Edwards, M.D. Davis, H.E. Blackmon, F.N. Scenna, N.R. Rohrbach, A.M. Saxton, H.S. Adair, F.M. Hopkins, J.C. Waller, and F.N. Schrick. 2005a. Effects of administration of ergotamine tartrate on fertility of yearling beef bulls. Theriogenology 63:1407-1418.

Schuenemann, G.M., J.L. Edwards, F.M. Hopkins, F.N. Scenna, J.C. Waller, J.W. Oliver, A.M. Saxton, and F.N. Schrick. 2005b. Fertility aspects in yearling beef bulls grazing endophyte-infected tall fescue pastures. Reprod. Fertil. Dev. 17:479-486.

Schumann, B., S. Dänicke, U. Meyer, K.H. Ueberschär, and G. Breves. 2007. Effects of different levels of ergot in concentrates on the growing and slaughtering performance of bulls and on carry-over into edible tissues. Arch. Anim. Nutr. 61:357-370.

Schumann, B., P. Lebzien, K.-H. Ueberschar, and S. Dänicke. 2009. Effects of the level of feed intake and ergot contaminated concentrate on ergot alkaloid metabolism and carry over into milk. Mol. Nutr. Food Res. 53:931-938.

Seath, D.M., C.A. Lassiter, G.M. Bastin, and R.F. Elliot. 1954. Effect of kind of pasture on the yield of TDN and on persistency of milk production of milk cows. Kentucky Exp. Stn. Bull. 609:3-11.

Sheaffer, C.C., and G.C. Martin. 1986. Effect of mefluidide on cool-season perennial grass forage yield and quality. Agron. J. 78:75-79.

Sheeler, L. V., C. Manley, G.R. Bratton, M.S. Amoss Jr., and G.B. Garner. 1985. Inhibition of prolactin release in dispersed bovine pituitary cell cultures by endophyte-infected rescue seed extract. J. Anim. Sci. 61(Suppl. 1):27.

Shelby, R.A. and L.W. Dalrymple. 1993. Long-term changes of endophyte-infection in tall fescue stands. Grass Forage Sci. 48:356-361.

Sibley, D.R., and I. Creese. 1983. Interactions of ergot alkaloids with anterior pituitary D-2 dopamine receptors. Mol. Pharmacol. 23L585-593.

Stuedemann, J.A., S.R. Wilkinson, D.P. Belesky, O.J. Devine, D.L. Breedlove, F.N. Thompson, C.S. Hoveland, H. Ciordia, and D.E. Townsend. 1985. Utilization and management of endophyte-infested tall fescue: Affects on steer performance and behavior. p. 17-20. In J.D. Miller (ed.) Proc. $41^{\text {st }}$ South. Pasture Forage Crop Imp. Conf. Raleigh, NC. 20-22 May. USDA/ARS U.S. Govt. Print. Office, Washington, DC.

Stuedemann, J.A., S.R. Wilkinson, D.P. Belesky, C.S. Hoveland, O.J. Devine, F.N. Thompson, H.C. McCampbell, W.E. Townsend, and H. Ciordia. 1986. Effect of level of fungus and nitrogen fertilization rate of KY-31 tall fescue on steer 
performance. J. Anim. Sci. 63(Suppl. 1):290-291.

Strickland, J.R., J.W. Oliver, and D.L. Cross. 1993. Fescue toxicosis and its impact on animal agriculture. Vet. Hum. Toxicol. 35:454-464.

Strickland, J.R., M.L. Looper, J.C. Matthews, C.F. Rosenkrans, Jr., M.D. Flythe, and K.R. Brown. 2011. Board-Invited review: St. Anthony's fire in livestock: Causes, mechanisms, and potential solutions. J. Anim. Sci. 89: 1603-1626.

Tanner, J.E., R.R. Frahm, R.L. Willham, and J.V. Whiteman. 1970. Sire x sex interactions and sex differences in growth and carcass traits of angus bulls, steers, and heifers. J. Anim. Sci. 1058-1064.

Turner, K.E., J.A. Paterson, M.S. Kerley, and J.R. Forwood. 1990. Mefluidide treatment of tall fescue pastures: Intake and animal performance. J. Anim. Sci. $68: 3399$.

Walker, J.W., R.K. Heitschmidt, E.A. De Moraes, M.M. Kothman, and S.L. Dowhoer. 1989. Quality and botanical of cattle diets under rotational and continuous grazing treatments. J. Range Manage. 42:239-242.

Waller, J.C. 2009. Endophyte effects on cattle. p. 289-310 in Tall fescue for the twenty-first century. H.A. Fribourgh, D.B. Hannaway, and C.P. West, ed. ASA, CSSA, and SSSA, Madison, WI.

Watson, R.H., M.A. McCann, J.A. Parish, C.S. Hoveland, F.N. Thompson, and J.H. Bouton. 2004. Productivity of cow-calf pairs grazing tall fescue pastures infected with either the wild-type endophyte or a nonergot alkaloid-producing endophyte strain, AR542. J. Anim. Sci. 82:3388-3393.

Wilkinson, S.R., J.A. Stuedemann, and D.J. Williams. 1983. Animal performance on tall fescue: Fat necrosis. Proc. Tall Fescue Toxicosis Workshop, Atlanta, GA. Univ. of Georgia Ext., Athens, GA.

Copyright (C Jessica A. Williamson 2015 


\section{VITA}

Jessica A. Williamson

\section{Education:}

- PhD Plant and Soil Science, University of Kentucky (In Progress)

o Dissertation: Animal and Pasture Responses to Grazing Management of Chemically Suppressed Tall Fescue in Mixed Pastures

- Co-Major Professor: Glen E. Aiken

- Co-Major Professor: Michael Barrett

- Cumulative GPA: 3.9

- M.S. Animal Science, University of Arkansas (2012)

o Thesis: Growth Promoting Implants and Nutrient Restriction Prior to Feeding: Effects on Carcass Composition, Carcass Quality, and Consumer Acceptability of Beef

- Major Professor: Paul A. Beck

- Cumulative GPA: 3.1

- B.S. Animal Science, Morehead State University (2009)

o Advisor: Troy J. Wistuba

o Cumulative GPA: 3.4

- Professional Experience:

o Graduate Research Assistant, University of Kentucky, 2013present.

O Graduate Research Assistant, University of Arkansas, 2010-2012.

o Lloyd Noble Scholar in Agriculture, Noble Foundation, 2010.

o Biological Technician Aide, USDA-ARS, Booneville, AR, 2009. 
o Undergraduate Research Fellow, Morehead State University, 20072009.

- Awards and Honors:

o Charles F. Barnes Graduate Research Competition, ASA-SSSACSSA Joint Annual Meeting, Long Beach, CA; $2^{\text {nd }}$ place

(November 2014)

o Gamma Sigma Delta Agriculture Honor Society (Inducted April 2014)

o National Champion Team, Coach, Forage Bowl, American Forage and Grasslands Council (AFGC), Memphis, Tennessee (January 2014)

o Abstract to Contract Graduate Research Poster Competition, $2^{\text {nd }}$ place in Agriculture division (University of Arkansas, Spring 2012)

o Lloyd Noble Scholar in Agriculture (January - August 2010)

o Dean's List (Fall 2008, Spring 2009, and Fall 2009)

\section{Teaching Experience:}

- Teaching Assistant

o Principles of Nutrition (Univ. of Arkansas, Spring 2011)

- Assist daily with class; tasks include lecturing, creating, proctoring and grading exams and quizzes

o Stocker and Feedlot Management (Univ. of Arkansas, Fall 2011)

- Chaperoned class trip to the Oklahoma Panhandle and across Kansas to see different stocker and feedlot operations

o Introductory to Animal Science (Univ. of Arkansas, Spring 2012)

- Assist daily with class; tasks include lecturing, organizing, providing transportation for, and teaching labs

\section{- Guest Lectures}

o Forage Utilization and Management (Univ. of Kentucky, Spring 2014)

- "Ruminant Digestive System Physiology and Anatomy and its Application to Nutrition"

o Beef Cattle Production (Penn State University, Spring 2014)

- "Beef Improvement Federation - Adjusted Production Measurements" 


\section{Publications:}

\section{Peer-reviewed:}

o Goff, B.M., G.E. Aiken, W.W. Witt, J.A. Williamson, E.S. Flynn, and P.L. Burch. 2014. Timing and Rate of Chaparral Treatment Affects Tall Fescue Seedhead Development and Pasture Plant Densities. Forage \& Grazinglands. 10.2134/FG-2013-0001-RS

o Williamson, J. A., R. R. Reuter, J. A. Apple, C. B. Stewart, H. C. Gray, and P. A. Beck. 2013. Growth promoting implants and nutrient restriction prior to feeding: effect on finishing performance, carcass composition, carcass quality, and consumer acceptability of beef. J. Anim. Sci. (submitted: MS\# E-20137170)

\section{Abstracts:}

o Robinette, J., R. Miculinich, B. Galbreath, T. Platt, and T. Wistuba. 2008. The effect of initial market grade on linear measurements and carcass characteristics of feeder goats. J. Anim. Sci. 87 (E-Supp 3): 119.

o Robinette, J.A., B. C. Williamson, R. Flores, J. B. Woolley, C. R. Bailey, L. M. Tharel, R. J. King, D. M. Burner, P. Carver, W. K. Coblentz, T. J. Wistuba, C. F. Rosenkrans, Jr., and M. L. Looper. 2009. In situ ruminal kinetics of DM and NDF disappearance for the biomass forages Amur silvergrass and big bluestem. 88 (ESupp 3): 113.

o Voyles, M., J. Robinette, T. Platt, T. Wistuba, M. Phillips, and G. Loneragan. 2009. Prevalence of Salmonella spp. in cow-calf herds grazing on pastures treated with poultry litter. 88 (E-Supp 3): 32.

o Robinette, J.A., P. Beck, B. Barham, S. Gadberry, and J. Apple. 2011. Effects of Implants and Nutrient Restrictions Prior to Feeding on Carcass Quality. 89 (ESupp 2): 1 . 
o Robinette, J.A., R. Reuter, P. Beck, F. Ribeiro, B. Stewart, H. Gray, J. Apple.

2012. Effect of pre-finishing implant strategy and nutrient restriction on finishing performance. 90 (E-Supp 1): 14.

o Alkire, D.O., J.A. Robinette, R.R. Reuter. The effect of livestock auction barn size and phenotypic traits on sale price of calves in Oklahoma. 90 (ESupp 1): 79 .

\section{Research Reports:}

o Robinette, J.A., B. C. Williamson, R. Flores, J. B. Woolley, C. R. Bailey, L. M. Tharel, R. J. King, D. M. Burner, P. Carver, W. K. Coblentz, T. J. Wistuba, C. F. Rosenkrans, Jr., and M. L. Looper. 2009. In situ ruminal kinetics of DM and NDF disappearance for the biomass forages Amur silvergrass and big bluestem. AAES Research Series 584: 20-23.

\section{Popular Press:}

o Reuter, R. and J. Robinette. March 2010. A.I. Calving Distribution. Ag News and Views. The Samuel Roberts Noble Foundation.

Copyright (C) Jessica A. Williamson 2015 